\title{
Uneven regulatory playing field and bank transparency abroad
}

\author{
Tai-Yuan Chen ${ }^{1}$, \\ Yi-Chun Chen $^{2}$ and \\ Mingyi Hung ${ }^{1}$

\footnotetext{
${ }^{1}$ The Hong Kong University of Science and Technology Business School, Clear Water Bay, Hong Kong; ${ }^{2}$ Department of Accountancy, City University of Hong Kong, 83 Tat Chee Avenue, Kowloon, Hong Kong
}

\section{Correspondence:}

M Hung, The Hong Kong University of Science and Technology Business School, Clear Water Bay, Hong Kong

e-mail: acmy@ust.hk

\begin{abstract}
Motivated by international business research on institutional arbitrage and headquarters-subsidiary relationships, we examine the effect of regulatory distance on multinational banks' (MNBs) reporting transparency abroad. Using an international sample of foreign subsidiary banks in 46 host countries from 47 home countries, we find that bank transparency declines when the home countries have tighter activity restrictions than the host countries. We bolster the causal inference using difference-in-differences designs that take advantage of banking reforms and cross-border bank acquisitions. We also find that the result is more pronounced when parent banks have lower capital ratios or when host countries have weaker supervisory power, suggesting that parent banks use opaque reporting to conceal risk-taking abroad. Further analysis finds that less transparent subsidiaries are more likely to fail during financial crises. Overall, our findings suggest that regulatory distance creates negative externalities for bank transparency and stability abroad.
\end{abstract}

Journal of International Business Studies (2022) 53, 379-404.

https://doi.org/ | 0.1057/s4 I267-021-0049|-6

Keywords: transparency within and among MNEs and national states; agency theory multinational corporations (MNCs) and enterprises (MNEs); headquarters-subsidiary roles and relations

The online version of this article is available Open Access

\section{INTRODUCTION}

Multinational banks (MNBs) play an important role in promoting international business through financing global transactions of multinational corporations and maintaining the stability of the global financial system (Fang, Hasan, Leung, \& Wang, 2019; Laeven, 2013). Cross-border banking claims reached more than half of world GDP in 2007, and the vast majority of these claims are held by global systemically important financial institutions (IMF, 2014a). However, bank regulations remain predominantly national and vary widely across countries (Barth, Caprio, \& Levine, 2013). While cross-country distance is a core concept in international business research, and the literature suggests that institutional distance generates arbitrage opportunities (Kostova, Beugelsdijk, Scott, Kunst, Chua, \& van Essen, 2020), there is little evidence on whether and how institutional arbitrage affects multinationals'
Supplementary Information The online version contains supplementary material available at https://doi.org/10.1057/s41267021-00491-6.

Received: 19 June 2020

Revised: 9 October 2021

Accepted: 15 November 2021

Online publication date: 10 January 2022 
financial reporting transparency. This study examines the following questions. Do the cross-country differences in bank restrictions affect financial reporting transparency of $\mathrm{MNBs}^{\prime}$ foreign subsidiaries? If so, how? What is the implication of transparency on bank failure during the crisis?

Institutional distance is particularly meaningful in the banking sector because banks are heavily regulated. Our focus is the regulatory restrictions on banks' securities, insurance, and real estate activities (hereafter, activity restrictions), because these are tightly linked to bank risk-taking (Karolyi \& Taboada, 2015; Ongena, Popov, \& Udell, 2013). ${ }^{1}$ Our emphasis on banks' financial reporting transparency stems from its importance to facilitate outside monitoring and discipline (Healy \& Palepu, 2001), which in turn mitigate banks' vulnerability to downside risk and enhance financial stability (Beatty \& Liao, 2014).

Shareholders of limited-liability banks with leveraged equity have incentives to take risk beyond the level that would be optimal for an "all-equity" bank (Barnea, Haugen, \& Senbet, 1985). Foreign subsidiaries enable parent banks to exploit lax hostcountry regulations and assume greater risk abroad, as they are separately capitalized and subject to host-countries' regulations. Rationally, debtholders and other stakeholders would recognize these incentive effects and price accordingly. Because the cost would be borne by the banks working on behalf of shareholders, it is to the best interests of banks and their shareholders to devise incentive compatible contracts, e.g., management compensation contracts (John, Saunders, \& Senbet, 2000). However, the incentive alignment can break down when the mechanism for pricing deposit insurance is inefficient and the financial markets are imperfect with insufficient signals. If regulatory environments are weak, banks can also walk away from their foreign subsidiaries, creating negative externalities. In this case, excess risk-taking via foreign subsidiaries will remain harmful, and MNBs will reduce the transparency of these subsidiaries to inhibit outside monitoring. Thus, our first hypothesis predicts that foreign subsidiaries' transparency declines when their home countries have tighter activity restrictions than their host countries.

Yet, parent banks may prefer consistent and transparent financial reporting throughout their global networks, to facilitate performance evaluation within an $\mathrm{MNB}$ and to reduce the cost of capital by reducing information asymmetry (Lambert, Leuz, \& Verrecchia, 2007; Roth \& O'Donnell,
1996). Parent banks may also take greater risk abroad to explore opportunities forbidden at home countries and to conceal these activities, due to concerns on proprietary costs of disclosure (Verrecchia, 1983).

Our second hypothesis predicts that foreign subsidiaries with lower transparency are more likely to fail during the financial crisis. The intuition is that opacity would inhibit market discipline and increase investors' uncertainty about bank fundamentals, thereby amplifying banks' vulnerability to downside risk (Bushman \& Williams, 2015). Note, however, that the effect of transparency on bank failure may be weak in our setting, because parent banks can inject internal capital to support financially distressed subsidiaries (Houston, James, \& Marcus, 1997).

Our empirical analysis focuses on majorityowned foreign subsidiary banks to ensure that parent banks control foreign subsidiaries' operations and reporting. We measure regulatory distance as the differences in an index of bank activity restrictions between the foreign subsidiaries' home and host countries. This index, obtained from Barth et al. (2013), captures the restrictiveness of bank regulations on nonlending activities, including trading securities, providing insurance, and investing in real estate. We measure bank transparency as the disclosures related to loans and securities, which constitute the majority of bank assets and capture bank risk-taking induced by regulatory distance (Karolyi \& Taboada, 2015; Ongena et al., 2013).

Our sample consists of 1617 subsidiary-years (300 subsidiaries) in 46 host countries from 47 home countries during 1995-2009. We test our first hypothesis using the observations from 1995 to 2006 and our second hypothesis using the observations from the 2007-2009 global financial crisis. Consistent with our predictions, we find that, after controlling for bank risk-taking, regulatory distance is negatively associated with foreign subsidiaries' transparency. This result is robust to alternative samples, subperiods, measures of bank transparency, estimation methods, and additional controls on other institutional distances. In addition, foreign subsidiaries with lower transparency prior to the crisis are more likely to fail or experience large deposit withdrawals during the crisis.

Because the interpretation that regulatory distance reduces bank transparency abroad is subject to endogeneity concerns, we use several approaches to strengthen the causal inferences. We include 
host country-year fixed effects to control for timevarying host-country characteristics throughout our analyses and implement an instrumental variable (IV) approach as a robustness check. In addition, we use difference-in-differences tests that exploit post-crisis banking reforms and cross-border bank acquisitions. We also use foreign branches from the same home country as the benchmark sample, because they are subject to home-country regulations and therefore do not provide an opportunity for parent banks to exploit regulatory distance (Ongena et al., 2013). Our inferences are unaffected by these alternative approaches. While these analyses may not fully eliminate the endogeneity concerns, cross-sectional tests on the underlying mechanisms further corroborate our inferences that parent banks use opaque reporting to conceal risk-taking abroad. Specifically, we find that our results are primarily driven by foreign subsidiaries controlled by parent banks with low capital ratios or are located in host countries with weak supervisory power, but not by foreign subsidiaries with high profitability.

Our findings contribute to the literature in several ways. First, we add to international business research on institutional distance by examining the consequences of MNBs' regulatory arbitrage on bank transparency abroad. While regulatory arbitrage is a key concern for regulators around the world, studies have yielded mixed conclusions on its consequences. The evidence of Frame, Mihov, \& Sanz (2020) and Ongena et al. (2013) is consistent with the value-destructive view of regulatory arbitrage, which argues for a harmful pursuit of excessive risk-taking, leading to a "race to the bottom." In contrast, the evidence of Houston, Lin, and Ma (2012) and Karolyi and Taboada (2015) is more consistent with the benign view, which posits a search for profitable investment opportunities abroad.

Second, we add to the burgeoning line of research on multinationals' subsidiary management (Kostova, Nell, \& Hoenen, 2016). Our study advances the theoretical development by integrating debt-equity agency conflicts with subsidiary reporting practices and empirically showing that foreign subsidiaries' transparency decreases in response to stringent home-country regulations. By documenting that this result varies with hostcountry supervisory power, we also add to research that examines the effects of country-level institutions on corporate transparency (Kanagaretnam, Lim, \& Lobo, 2014).
Finally, our paper extends the literature on the relationship between bank transparency and performance (Beatty \& Liao, 2014; Bushman \& Williams, 2015). To the best of our knowledge, our study is the first to examine the reporting transparency of foreign subsidiary banks and its consequences. Our study complements the work of Ongena et al. (2013), who directly observed loans by foreign subsidiary banks and found that tighter activity restrictions at home are associated with lower lending standards abroad.

We also provide policy implications for regulators worldwide by highlighting the importance of disclosure practices among MNBs' foreign subsidiaries. Given that financial systems are increasingly interconnected across countries, the failure of foreign subsidiaries may amplify risk contagions beyond the local market.

The rest of the article is organized as follows. The second section summarizes the literature and develops our hypotheses. The third describes the sample and data. The fourth presents empirical results. The fifth reports difference-in-differences analyses and explores mechanisms. The last section concludes.

\section{THEORETICAL BACKGROUND AND HYPOTHESES}

\section{Institutional Arbitrage and Headquarters- Subsidiary Relationships}

National contexts and contextual embeddedness of organizations lie at the heart of international business research (Kostova et al., 2020). Since multinationals conduct business through multiple subsidiaries in different countries, research has extensively studied the construct and impact of cross-country contextual distance on organizational outcomes and recognizes that international management is essentially the "management of distance" (Beugelsdijk, Nell, \& Ambos, 2017). One notable line of the research identifies strategies of institutional arbitrage; that is, multinationals take advantage of the institutional distance between home and host country to optimize their global investment portfolio.

The literature also suggests that MNBs, by taking advantage of regulatory distance, enjoy more investment opportunities in countries with less restrictive regulations (Ongena et al., 2013). ${ }^{2}$ Despite the interdependence of the global banking system, bank regulations vary widely around the 
world (Barth et al., 2013; Čihák, Demirgüç-Kunt, Martínez Pería, \& Mohseni-Cheraghlou, 2012). MNBs are key players in the global banking system and can exploit institutional distance through their foreign subsidiaries. ${ }^{3}$ Subject to host-country regulations, foreign subsidiaries offer MNBs the opportunities to take on risky projects prohibited by home-country regulations. As subsidiaries are legally separate from their parents, MNBs also bear limited exposure when the subsidiaries fail. Under most circumstances, MNBs' losses would be limited to the equity investment in the subsidiaries (Cerutti, Dell'Ariccia, \& Martínez Pería, 2007; Fiechter, et al., 2011). Thus, the primary bad outcome for MNBs is the equity investment in foreign subsidiaries and reputational cost.

\section{Regulatory Distance and Foreign Subsidiaries' Transparency}

Shareholders of limited-liability banks financed by deposits (whether insured or uninsured) have incentives to push risk beyond the optimal level for an "all equity" bank (John et al., 2000). Debtholder or other stakeholders would rationally recognize these incentives and price-protect themselves against potential losses and monitoring costs. Because banks and their shareholders bear the agency costs, they would design contracts to promote incentive alignment and to curb excessive risk-taking (Barnea et al., 1985; Green, 1984). Pervasive deposit protection, through government guarantee and deposit insurance, transfers risks to governments (Demirgüç-Kunt, Kane, \& Laeven, 2015). John et al. (2000) suggest that, by incorporating incentive features of compensation as an input to the price of deposit insurance, the pricing of deposit insurance can become an instrument for bank owners to declare an optimal management compensation structure that produces incentive alignment. However, this incentive alignment may break down in weak institutions, where the mechanism for pricing deposit insurance is inefficient and the financial markets are imperfect with insufficient pricing signals (Cull, Senbet, \& Sorge, 2005).

Furthermore, frictions exist in the supervision of international banks. Bank supervisors implement various regulatory mechanisms to constrain risktaking to protect taxpayers' money, but these mechanisms may not be effective when institutions are weak. In countries with weak regulations or incompetent/corrupt governments, MNBs can walk away from their subsidiaries and impose negative externalities. While bank supervision should be conducted on a consolidated basis, it is relatively difficult for home-country supervisors to coordinate with host-country supervisors to monitor MNBs' foreign subsidiaries (D'Hulster, 2012).

The regulatory differences across countries provide incentives for MNBs to take more risk through their foreign subsidiaries when they face greater restrictions at home. Studies suggest that MNBs embark on a deliberate strategy of risk-taking abroad to compensate for the inability to take on risk in their home market (Karolyi \& Taboada, 2015; Ongena et al., 2013). ${ }^{4}$ If the design of incentives is inefficient in the regulatory space, the risk-taking will remain harmful, and MNBs will decrease their foreign subsidiaries' transparency to prevent outside discipline. This leads to our first hypothesis.

Hypothesis 1: Foreign subsidiaries' transparency declines when their home-country regulations have tighter activity restrictions than their host-country regulations.

There are, however, countervailing arguments for why restrictive home-country regulations do not impair transparency abroad. Parent banks may aim to hold a consistent reporting approach across their subsidiaries. A consistent set of reporting practices within a global network would yield various benefits, including improved comparability and performance evaluation (Roth \& O'Donnell, 1996). Moreover, parent banks may choose transparent reporting to attract external financing. Studies suggest that transparency reduces information asymmetry that in turn decreases the cost of capital (Lambert et al., 2007). Finally, parent banks may reduce the financial reporting transparency of their foreign subsidiaries, due to proprietary cost considerations. Because information revealed through disclosures can deprive banks of their competitive advantage, banks may decrease disclosures to maintain their competitive advantage and deter the entrance of potential competitors (Verrecchia, 1983).

\section{Foreign Subsidiaries' Transparency and Bank Failure}

Our second hypothesis predicts that foreign subsidiaries' lower transparency increases the likelihood of failure during the crisis. One reason is that lower transparency increases investors' uncertainty about bank fundamentals and thus amplifies the financing frictions during the crisis (Bushman \& 
Williams, 2015). Another reason is that opacity hinders the ability of market participants to promptly pressure regulators to intervene in troubled banks. This leads to our second hypothesis.

Hypothesis 2: Foreign subsidiaries with lower transparency are more likely to fail during the financial crisis.

Note, however, that prior results may not be generalizable to our setting, because parent banks can inject capital to support their financially distressed subsidiaries (Houston et al., 1997).

\section{DATA AND VARIABLES}

\section{Data and Sample Selection}

We obtain foreign subsidiaries' financial statement data on an unconsolidated basis from Bankscope, a database commonly used in international banking research (Fang et al., 2019; Frame et al., 2020). We use 1995-2006 for our first hypothesis test and 2007-2009 for our second hypothesis test. We focus on foreign subsidiaries, because they are separately capitalized and subject to host-country regulations, allowing parent banks to arbitrage regulations. We restrict our analysis to majority-owned foreign subsidiaries, because their operations and reporting are under parent banks' direct control.

Our initial sample consists of 2814 majorityowned subsidiary banks in the Bankscope parentsubsidiary link table. ${ }^{5}$ We impose the following criteria. First, for subsidiaries with multiple ownership observations, we drop the observations that lack a direct link to ensure a unique parentsubsidiary link for each subsidiary (281 subsidiaries). ${ }^{6}$ Second, because Bankscope only retains the most recent ownership data, we drop all the subsidiary-years that belong to M\&A targets in cross-border majority control acquisitions during our sample period (147 subsidiaries). Third, we delete domestic subsidiaries (i.e., subsidiaries located in the same country where parent banks are headquartered, 968 subsidiaries). Finally, we drop subsidiaries that do not have financial statement data (646 subsidiaries) or country-level bank regulation indexes (22 subsidiaries). We also drop the subsidiaries that do not have necessary data for our analysis, represent the only subsidiary in the host country-year, or do not have loans or securities on balance sheets (450 subsidiaries). Our final sample consists of 300 majority-owned foreign subsidiaries (1617 subsidiary-year observations) in
46 host countries from 1995 to 2009. These subsidiaries are owned by 190 parent banks from 47 home countries. This sample structure, with multiple home and host countries, enables us to isolate regulatory distance from institutional profile effects of the host countries.

Table 1, Panel A, reports the sample selection procedure. Panel B compares the characteristics between the final sample (300 subsidiaries) and the foreign subsidiaries that are dropped but have basic financial data ( $472=772-300$ subsidiaries). We find that the geographic distributions between these two groups differ slightly. The final sample also contains larger subsidiaries with lower profitability and capital ratios, on average. While we control for these characteristics throughout our analyses, we acknowledge that the external validity of our findings is restricted to our sample banks.

Table 1, Panel C, reports the sample distribution by year. ${ }^{7}$ Panel $\mathrm{D}$ reports the sample distribution by home country (i.e., the country where the parent bank is headquartered). We find that banks from France have the highest number of foreign subsidiaries (29), followed by Germany and the UK (26) and Japan (21). ${ }^{8}$ This is not surprising because these countries are home to large MNBs, such as BNP Paribas (France), Deutsche Bank (Germany), Nomura Holdings (Japan), and Standard Chartered (the UK). Panel E presents the sample distribution by host country (i.e., the country where the subsidiary is located). We find that Switzerland has the most foreign subsidiaries (41), followed by Luxembourg (37), and Germany and the UK (21). While these four countries are generally considered to have high-quality regulation, their approach to bank supervision varies. Based on the median of country-level supervisory power (11.00), Luxemburg (12.25) and Switzerland (13.00) grant bank supervisors high power to intervene in bank operations and to correct problems, while Germany (9.25) and the UK (10.00) grant low power. Overall, our sample is geographically dispersed, rather than dominated by specific countries, which helps ensure the generalizability of our findings.

\section{Variables}

We measure regulatory distance, $\triangle$ RESTRICT, as the index of home-country activity restrictions minus the index of host-country activity restrictions. The activity restrictions index (RESTRICT) comes from Barth et al. (2013). ${ }^{9}$ The index ranges from 3 to 12 , with higher values indicating more restrictive regulations on banks' securities, insurance, and real 
Table 1 Sample selection and distribution

\begin{tabular}{|c|c|c|c|c|}
\hline \multicolumn{5}{|c|}{ Panel A: Sample selection } \\
\hline & $\begin{array}{l}\text { No of subsidiaries associated } \\
\text { with each step }\end{array}$ & $\%$ & $\begin{array}{l}\text { Total no. of } \\
\text { subsidiaries } \\
\text { after each } \\
\text { step }\end{array}$ & $\%$ \\
\hline Majority-owned subsidiaries, 1995-2009 & & & 2,814 & 100 \\
\hline Subsidiaries without direct ownership & -281 & -9.99 & 2,533 & 90.01 \\
\hline M\&A targets & -147 & -5.22 & 2386 & 84.79 \\
\hline Domestic subsidiaries & -968 & -34.40 & 1,418 & 50.39 \\
\hline Subsidiaries without financial statement data & -646 & -22.96 & 772 & 27.43 \\
\hline Missing bank regulation index & -22 & -0.78 & 750 & 26.65 \\
\hline $\begin{array}{l}\text { Missing required variables (including loan or securities) and } \\
\text { only one in host country-year }\end{array}$ & -450 & -15.99 & 300 & 10.66 \\
\hline
\end{tabular}

Panel B: Comparison of final sample and other majority-owned foreign subsidiaries that are not retained in the final sample

\begin{tabular}{|c|c|c|c|c|c|c|c|}
\hline \multirow[t]{3}{*}{ Variable } & \multicolumn{3}{|c|}{ Final sample } & \multicolumn{3}{|c|}{ Other foreign majority-owned sub. } & \multirow[b]{3}{*}{ Diff. } \\
\hline & \multicolumn{3}{|c|}{ No. of sub. $=300,1995-2009$} & \multicolumn{3}{|c|}{ No. of sub. $=472,1995-2009$} & \\
\hline & $\begin{array}{l}\mathrm{n} \\
(1)\end{array}$ & $\begin{array}{l}\% \\
(2)\end{array}$ & $\begin{array}{l}\text { Mean } \\
\text { (3) }\end{array}$ & $\begin{array}{l}\mathrm{n} \\
(4)\end{array}$ & $\begin{array}{l}\% \\
(5)\end{array}$ & $\begin{array}{l}\text { Mean } \\
(6)\end{array}$ & \\
\hline \multicolumn{8}{|c|}{ Geographic distribution, home country } \\
\hline Europe & 209 & 69.67 & n.a. & 252 & 53.39 & n.a. & $16.28 \%$ \\
\hline Asia & 55 & 18.33 & n.a. & 105 & 22.25 & n.a. & $-3.91 \%$ \\
\hline Americas & 23 & 7.67 & n.a. & 60 & 12.71 & n.a. & $-5.05 \%$ \\
\hline Africa & 8 & 2.67 & n.a. & 41 & 8.69 & n.a. & $-6.02 \%$ \\
\hline Oceania & 5 & 1.67 & n.a. & 14 & 2.97 & n.a. & $-1.30 \%$ \\
\hline \multicolumn{8}{|c|}{ Geographic distribution, host country } \\
\hline Europe & 197 & 65.67 & n.a. & 203 & 43.01 & n.a. & $22.66 \%$ \\
\hline Asia & 35 & 11.67 & n.a. & 112 & 23.73 & n.a. & $-12.06 \%$ \\
\hline Americas & 38 & 12.67 & n.a. & 88 & 18.64 & n.a. & $-5.98 \%$ \\
\hline Africa & 18 & 6.00 & n.a. & 55 & 11.65 & n.a. & $-5.65 \%$ \\
\hline Oceania & 12 & 4.00 & n.a. & 14 & 2.97 & n.a. & $1.03 \%$ \\
\hline \multicolumn{8}{|c|}{ Financial characteristics } \\
\hline Size & 1617 & n.a. & 7.409 & 2257 & n.a. & 6.094 & 1.316 \\
\hline Roa & 1617 & n.a. & 0.011 & 2108 & n.a. & 0.016 & -0.005 \\
\hline Capital ratio & 1617 & n.a. & 0.123 & 2859 & n.a. & 0.215 & -0.091 \\
\hline
\end{tabular}

Panel C: Sample distribution by year

\begin{tabular}{|c|c|c|c|c|c|c|c|c|c|c|c|}
\hline \multicolumn{12}{|c|}{ Pre-crisis period $(\mathrm{N}$, sub.-years $=1102)$} \\
\hline 1995 & 1996 & 1997 & 1998 & 1999 & 2000 & 2001 & 2002 & 2003 & 2004 & 2005 & 2006 \\
\hline 4 & 22 & 30 & 31 & 45 & 60 & 89 & 178 & 181 & 162 & 155 & 145 \\
\hline \multicolumn{12}{|c|}{ Panel C: Sample distribution by year } \\
\hline \multicolumn{6}{|c|}{ Crisis period $(\mathrm{N}$, sub.-years $=515)$} & & \multicolumn{3}{|c|}{ N (sub.-years) } & \multirow{2}{*}{\multicolumn{2}{|c|}{$N$ (subs.) }} \\
\hline 2007 & & \multicolumn{2}{|c|}{2008} & \multicolumn{3}{|c|}{2009} & \multicolumn{3}{|c|}{ Total } & & \\
\hline 152 & & \multicolumn{2}{|c|}{167} & \multicolumn{3}{|c|}{196} & \multicolumn{3}{|c|}{1617} & \multicolumn{2}{|r|}{300} \\
\hline
\end{tabular}


Table 1 continued

\begin{tabular}{|c|c|c|c|c|c|c|c|c|c|c|c|}
\hline \multicolumn{12}{|c|}{ Panel D: Sample distribution by home country } \\
\hline Region & $\begin{array}{l}\text { Home } \\
\text { country }\end{array}$ & \multicolumn{2}{|c|}{$\begin{array}{l}\text { No., sub.- } \\
\text { years }\end{array}$} & $\begin{array}{l}\%, \text { sub.- } \\
\text { years }\end{array}$ & $\begin{array}{l}\text { No., } \\
\text { subs. }\end{array}$ & Region & $\begin{array}{l}\text { Home } \\
\text { country }\end{array}$ & \multicolumn{2}{|c|}{$\begin{array}{l}\text { No., sub.- } \\
\text { years }\end{array}$} & $\begin{array}{l}\%, \text { sub.- } \\
\text { years }\end{array}$ & $\begin{array}{l}\text { No., } \\
\text { subs. }\end{array}$ \\
\hline \multirow[t]{19}{*}{ Europe } & Germany & \multicolumn{2}{|c|}{190} & 11.75 & 26 & Asia & Singapore & \multicolumn{2}{|c|}{25} & 1.55 & 3 \\
\hline & France & \multicolumn{2}{|c|}{155} & 9.59 & 29 & & Israel & 17 & & 1.05 & 4 \\
\hline & UK & 122 & & 7.54 & 26 & & Hong Kong & 15 & & 0.93 & 4 \\
\hline & Switzerland & 106 & & 6.56 & 18 & & Kuwait & 12 & & 0.74 & 2 \\
\hline & Austria & 100 & & 6.18 & 20 & & Turkey & 11 & & 0.68 & 4 \\
\hline & Luxembourg & 87 & & 5.38 & 14 & & Bahrain & 11 & & 0.68 & 2 \\
\hline & Italy & 73 & & 4.51 & 15 & & Thailand & 10 & & 0.62 & 1 \\
\hline & Spain & 66 & & 4.08 & 15 & & Other & 33 & & 2.04 & 6 \\
\hline & Netherlands & 61 & & 3.77 & 10 & & Subtotal & 273 & & 16.88 & 55 \\
\hline & Sweden & 55 & & 3.40 & 8 & Americas & Canada & 75 & & 4.64 & 10 \\
\hline & Belgium & 30 & & 1.86 & 8 & & Brazil & 15 & & 0.93 & 4 \\
\hline & Russia & 26 & & 1.61 & 4 & & US & 15 & & 0.93 & 5 \\
\hline & Denmark & 19 & & 1.18 & 3 & & Other & 5 & & 0.31 & 4 \\
\hline & Greece & 18 & & 1.11 & 2 & & Subtotal & 110 & & 6.80 & 23 \\
\hline & Liechtenstein & 16 & & 0.99 & 2 & Africa & South Africa & 24 & & 1.48 & 4 \\
\hline & Slovenia & 14 & & 0.87 & 2 & & Egypt & 6 & & 0.37 & 1 \\
\hline & Norway & 12 & & 0.74 & 2 & & Other & 7 & & 0.43 & 3 \\
\hline & Other & 11 & & 0.68 & 5 & & Subtotal & 37 & & 2.29 & 8 \\
\hline & Subtotal & 1,16 & & 71.80 & 209 & Oceania & Australia & 36 & & 2.23 & 5 \\
\hline Asia & Japan & 101 & & 6.25 & 21 & & Subtotal & 36 & & 2.23 & 5 \\
\hline & South Korea & 38 & & 2.35 & 8 & & Total & 1,617 & & 100.00 & 300 \\
\hline & & & & Panel E: S & ample distri & bution by $\mathrm{h}$ & ost country & & & & \\
\hline Region & Host country & & $\begin{array}{l}\text { No., } \\
\text { sub.-years }\end{array}$ & $\begin{array}{l}\%, \\
\text { sub.-year }\end{array}$ & $\begin{array}{l}\text { No., } \\
\text { subs. }\end{array}$ & Region & $\begin{array}{l}\text { Host } \\
\text { country }\end{array}$ & & $\begin{array}{l}\text { No., } \\
\text { sub.-years }\end{array}$ & $\begin{array}{l}\%, \\
\text { sub.-years }\end{array}$ & $\begin{array}{l}\text { No., } \\
\text { subs. }\end{array}$ \\
\hline Europe & Luxembourg & & 296 & 18.31 & 37 & Asia & Indonesia & & 21 & 1.30 & 5 \\
\hline & Switzerland & & 283 & 17.50 & 41 & & Hong Kong & & 18 & 1.11 & 7 \\
\hline & UK & & 130 & 8.04 & 21 & & Singapore & & 17 & 1.05 & 4 \\
\hline & Germany & & 115 & 7.11 & 21 & & Macao & & 13 & 0.80 & 4 \\
\hline & Czech Repub & & 44 & 2.72 & 8 & & Other & & 18 & 1.11 & 6 \\
\hline & France & & 41 & 2.54 & 7 & & Subtotal & & 148 & 9.15 & 33 \\
\hline & Netherlands & & 34 & 2.10 & 7 & Americas & Brazil & & 63 & 3.90 & 12 \\
\hline & Poland & & 30 & 1.86 & 8 & & US & & 20 & 1.24 & 11 \\
\hline & Belgium & & 26 & 1.61 & 5 & & Argentina & & 14 & 0.87 & 2 \\
\hline & Croatia & & 25 & 1.55 & 5 & & Chile & & 12 & 0.74 & 2 \\
\hline & Spain & & 25 & 1.55 & 5 & & Uruguay & & 10 & 0.62 & 2 \\
\hline & Malta & & 23 & 1.42 & 5 & & Other & & 20 & 1.24 & 9 \\
\hline & Austria & & 23 & 1.42 & 4 & & Subtotal & & 139 & 8.60 & 38 \\
\hline & Latvia & & 22 & 1.36 & 3 & Africa & Botswana & & 18 & 1.11 & 3 \\
\hline & Ireland & & 20 & 1.24 & 7 & & Mauritius & & 14 & 0.87 & 4 \\
\hline & Italy & & 19 & 1.18 & 4 & & Malawi & & 10 & 0.62 & 2 \\
\hline & Hungary & & 14 & 0.87 & 2 & & Other & & 17 & 1.05 & 9 \\
\hline & Liechtenstein & & 12 & 0.74 & 3 & & Subtotal & & 59 & 3.65 & 18 \\
\hline & Estonia & & 10 & 0.62 & 2 & Oceania & Australia & & 49 & 3.03 & 9 \\
\hline & Other & & 4 & 0.25 & 2 & & New Zealanc & & 26 & 1.61 & 3 \\
\hline & Subtotal & & 1,196 & 73.96 & 197 & & Subtotal & & 75 & 4.64 & 12 \\
\hline Asia & Malaysia & & 61 & 3.77 & 7 & & Total & & 1,617 & 100.00 & 300 \\
\hline
\end{tabular}

Reports the sample selection and distribution of foreign subsidiaries. Panel A reports the sample selection procedure and Panel B reports the comparison between the final sample and subsidiaries excluded from the analyses. Panels C, D, and E present the sample distribution by year, home country, and host country, respectively 
estate activities. We focus on regulatory distance ( $\triangle$ RESTRICT) because parent banks' risk-taking should be influenced as much by the regulatory environment in home countries as by that in host countries. A higher value of $\triangle$ RESTRICT indicates more stringent restrictions at home. Appendix A provides detailed definitions of the variables. Table A of the internet appendix presents the average value of the activity restrictions index by country. ${ }^{10}$

Our measure of bank transparency, DISCLOSURE, is an index of aggregate disclosure that captures the level of disclosures related to loans and securities. We focus on loans and securities, because they account for the majority of total bank assets (Beatty \& Liao, 2014). In addition, given that tighter activity restrictions at home lead to lower lending standards and more investment activities abroad (Karolyi \& Taboada, 2015; Ongena et al., 2013), the disclosures related to loans and securities can directly capture the effect of regulatory distance on bank transparency. DISCLOSURE is the sum of two sub-indexes: (1) DISCLOSURE_LOAN, which measures whether the subsidiary discloses loan types, the amount of loan loss provisions, and the amount of nonperforming loans, and (2) DISCLOSURE_SEC, which measures whether the subsidiary discloses securities types, issuing party, the amount of gains (losses) on trading and derivatives, and the amount of available-for-sale valuation adjustment. Table $B$ of the internet appendix describes the construction of the disclosure index and provides examples.

While our approach of measuring disclosure through a count of nonmissing values comports with the approach used elsewhere (e.g., Baumann \& Nier, 2004; Chen, Miao, \& Shevlin, 2015), we acknowledge that our approach is subject to measurement errors (i.e., coding an item as missing when the bank does not lend or trade or when the information is publicly available elsewhere). To mitigate the errors, we require our sample banks to have nonmissing values for loan and security holdings. We also contact Bankscope representatives to validate the data coverage. The response indicates that Bankscope collects financial information from various sources, including banks and local regulators. To the extent that banks' financial information is subject to disclosure regulations and can facilitate counter-party transactions, ${ }^{11}$ it is reasonable to interpret the missing value as nonpublic disclosure.
Although Generally Accepted Accounting Principles (such as US GAAP or IFRS) provide a basic framework and minimum requirements for financial disclosures, considerable latitude remains in determining what information is provided and how it is presented (Chen et al., 2015). As managers have discretion in choosing which items are material and how to aggregate line items, DISCLOSURE reflects their discretionary choices within GAAP. ${ }^{12}$

Studies commonly use the timeliness or estimation errors of loan loss provisions as the proxy for bank transparency (e.g., Bushman \& Williams, 2015). We do not use these proxies because discretionary loan loss provisions may reflect managers' private information, opportunistic earnings management, or both. In contrast, DISCLOSURE directly captures bank transparency and avoids the challenges of interpreting discretionary loan loss provisions. Further, using DISCLOSURE to measure bank transparency can avoid the significant decrease in sample size (i.e., the loan loss provisions model requires the disclosures of loan loss provisions and nonperforming loans).

Our primary proxy for bank failure, BANK FAILURE, is an indicator variable equal to one if the bank existed prior to the crisis but ceases to have financial statement information during the crisis and becomes inactive thereafter. ${ }^{13}$ This measure likely captures the extreme outcome that the subsidiary is liquidated or dissolved. ${ }^{14}$ We also use a supplement measure, LARGE DEPOSIT WD, that captures whether the bank experiences a large deposit withdrawal during the crisis (Iyer \& Puri, 2012).

\section{Descriptive Statistics}

Table 2, Panels A and B, present the descriptive statistics and correlation coefficients for the sample testing our first hypothesis (1,102 subsidiary-years from 1995 to 2006). We winsorize all continuous variables at the top and bottom $1 \%$ of their distributions. Panel A shows that the mean $\triangle$ RESTRICT is 0.184 , indicating that on average the home countries have more restrictive regulations than the host countries. ${ }^{15}$ The mean DISCLOSURE is 2.883 , suggesting that the subsidiaries disclose less than three pieces of information related to their lending and trading. The mean DISCLOSURE_LOAN is 1.757 , and the mean DISCLOSURE_SEC is 1.126 , indicating that banks provide less information regarding trading than lending. The mean and median total assets of our sample subsidiaries are $\$ 7,310$ million and $\$ 1,503$ million. ${ }^{16}$ The mean 
ROA and CAPITAL RATIO is $1.1 \%$ and $11.8 \%$, suggesting that the subsidiaries are financially healthy and well capitalized. Finally, we find that $79 \%$ of the subsidiaries are audited by Big Five auditors and only $4 \%$ are publicly listed. ${ }^{17}$ Panel B shows that $\triangle$ RESTRICT and DISCLOSURE are negatively correlated.

Table 2, Panels $\mathrm{C}$ and $\mathrm{D}$, present the descriptive statistics and correlation coefficients for the sample testing our second hypothesis (145 subsidiaries that existed in 2006). In Panel $C$, the number of observations for the variable LARGE DEPOSIT WD is reduced to 135 , because we exclude the 10 failed banks. The mean BANK FAILURE is $7 \%$, and the mean LARGE DEPOSIT WD is $21 \%$. Panel D shows that BANK FAILURE and DISCLOSURE are negatively correlated (correlation coeff. $=-0.19$ ).

\section{EMPIRICAL RESULTS}

\section{Regulatory Distance and Foreign Subsidiaries' Transparency}

We test our first hypothesis by regressing the aggregate disclosure index (DISCLOSURE) on the regulatory distance between home and host countries ( $\triangle$ RESTRICT). We control for the following bank characteristics that explain banks' financial reporting quality (Kanagaretnam et al., 2014): (1) SIZE, the log of lagged total assets; (2) ROA, return on assets; (3) LOAN GROWTH, the growth of total loans; (4) CAPITAL RATIO, shareholder equity divided by total assets; (5) BIG 5, a variable indicating whether the subsidiary is a client of a Big Five auditor; and (6) PUBLIC, a variable indicating whether the subsidiary is publicly listed. In addition, we include a variable indicating whether the home and host countries share the same official language (SAME LANGUAGE) to control for the barriers to communication and supervision across countries. Because parent banks likely determine their financial reporting practices based on the strength of bank supervision and deposit insurance, we control for $\triangle$ SUPV POWER, an index that measures the extent to which the bank supervisors can take specific actions to prevent or correct problems, and $\triangle$ DEPOSIT INS, an indicator variable equal to one if there is explicit deposit insurance and depositors were fully compensated the last time a bank failed.

We also control for a bank's distance-to-default, LOG Z, because riskier banks may face greater demand for information or have incentives to decrease disclosure to deter outside monitoring. Following prior studies (Laeven \& Levine, 2009), we measure LOG $\mathrm{Z}$ as the natural logarithm of mean($\mathrm{ROA}+\mathrm{CAR}) /$ volatility(ROA), where ROA is the return on assets and CAR is the capital to asset ratio. We include entity-type fixed effects, $\delta$, to control for the types of the subsidiaries, ${ }^{18}$ and host country-year fixed effects, $\eta$, to control for local country-year accounting practices and regulatory/ economic factors. Our regression model follows:

$$
\begin{aligned}
\text { DISCLOSURE }= & \beta_{0}+\beta_{1} \Delta \text { RESTRICT }+\beta_{2} \text { SIZE } \\
& +\beta_{3} \text { ROA }+\beta_{4} \text { LOAN GROWTH } \\
& +\beta_{5} \text { CAPITAL RATIO }+\beta_{6} \text { BIG5 } \\
& +\beta_{7} \text { PUBLIC }+\beta_{8} \text { SAME LANGUAGE } \\
& +\beta_{9} \Delta \text { SUPV POWER } \\
& +\beta_{10} \Delta \text { DEPOSIT INS }+\beta_{11} \text { LOG Z } \\
& +\delta+\eta+\varepsilon
\end{aligned}
$$

Our first hypothesis predicts $\beta_{1}$, the coefficient on $\triangle$ RESTRICT, to be negative. Because DISCLOSURE is an ordinal variable, we use Ordered probit regression model. We cluster standard errors by host country-year following Ongena et al. (2013).

Table 3, Panel A, presents the regression results. Column (1) shows that the coefficient on $\triangle$ RESTRICT is $-0.073(p=0.001)$, suggesting that foreign subsidiaries' transparency decreases when their home-country regulations are more restrictive than their host-country regulations. In terms of economic significance, a one standard deviation increase of $\triangle$ RESTRICT from the mean reduces the probability of disclosing four pieces of information related to lending and securities activities from $11.60 \%$ to $8.30 \%$ when all other variables equal their means. ${ }^{19}$ Column (2) confirms our results using an ordinary least squares (OLS) regression model because non-linear Ordered probit models with many fixed effects may suffer from incidental parameter bias (Greene, 2004).

To address the endogeneity concern, Column (3) reports the results using the IV approach. We use two home-country variables as instruments: (1) bank competition, ENTRY BARRIER, a measure of the limitation on foreign bank entry/ownership (Barth et al., 2013), and (2) exogenous growth opportunity, GGO, a measure of country-specific growth opportunity implied by the global market (Bekaert, Harvey, Lundblad, \& Siegel, 2007). As activity restriction is to prevent banks from non- 
ฉ|

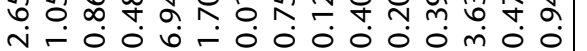

\section{,}

$\tilde{o}$

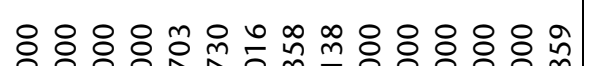

i

는

$\Sigma$

$m n-r-n 00-00-0 m$

অ

$\stackrel{\sqrt[\pi]{0}}{\sum}$

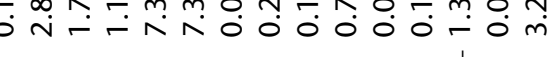

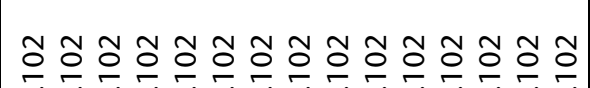

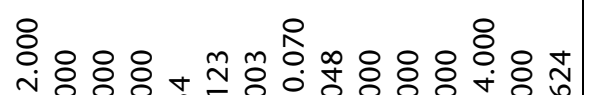

1 i

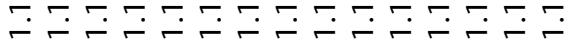

$\dot{2}$

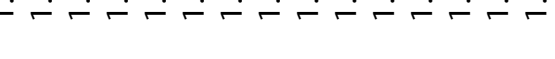

永

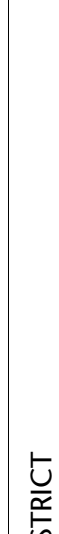

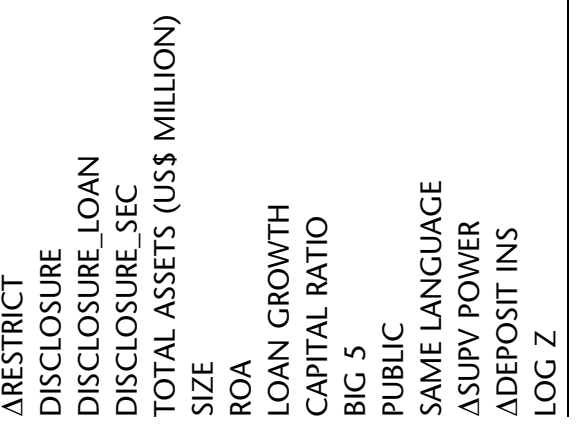

$\stackrel{\widehat{m}}{=}$

$\underset{\overparen{C}}{\check{C}}$

E

은

()

$\widehat{\infty}$

$\widehat{E}$

e

ลี

$\widehat{Ð}$

๓ุ

ฮ

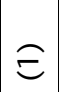

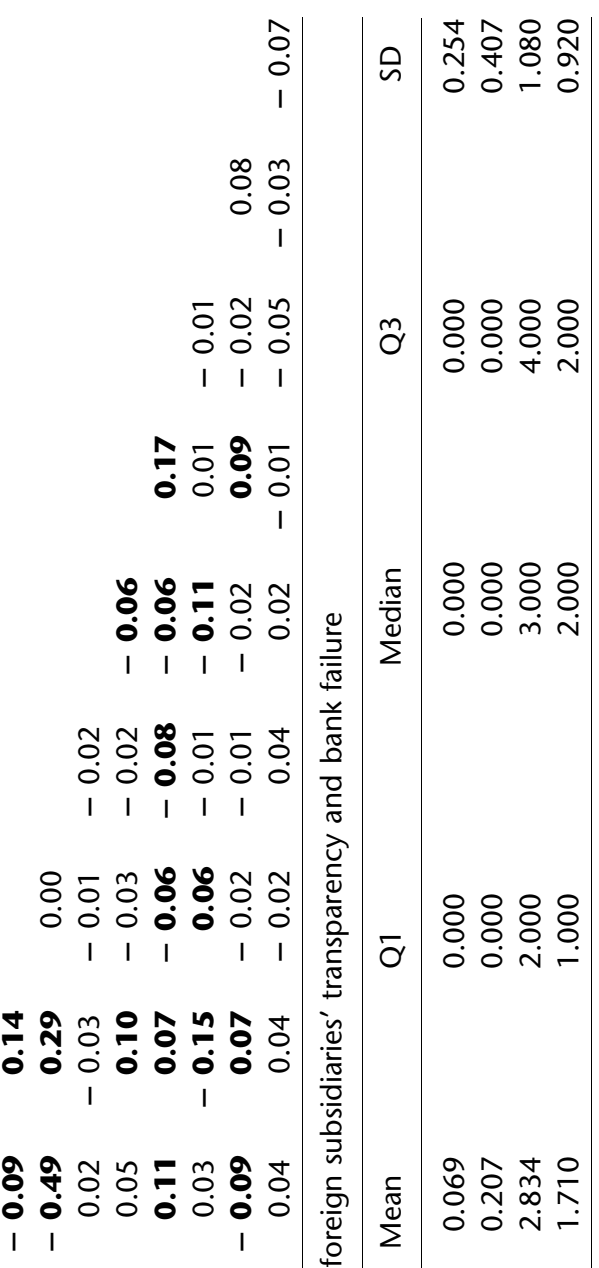

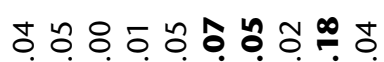

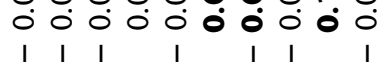

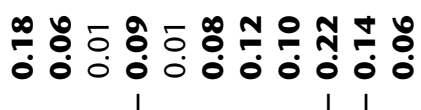

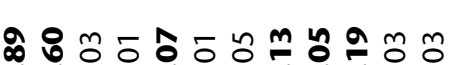

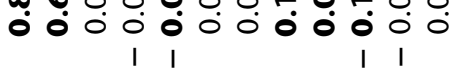

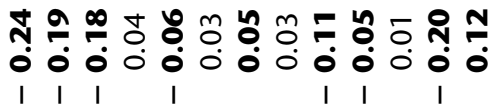

疋

崖岕崖

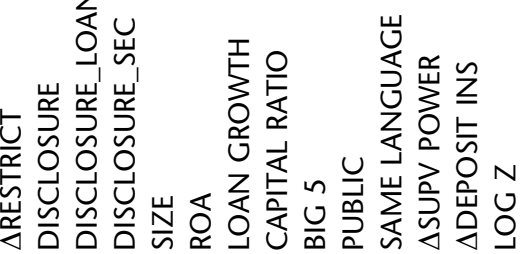

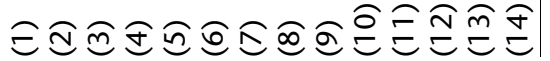

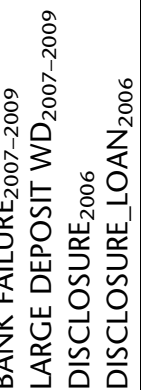




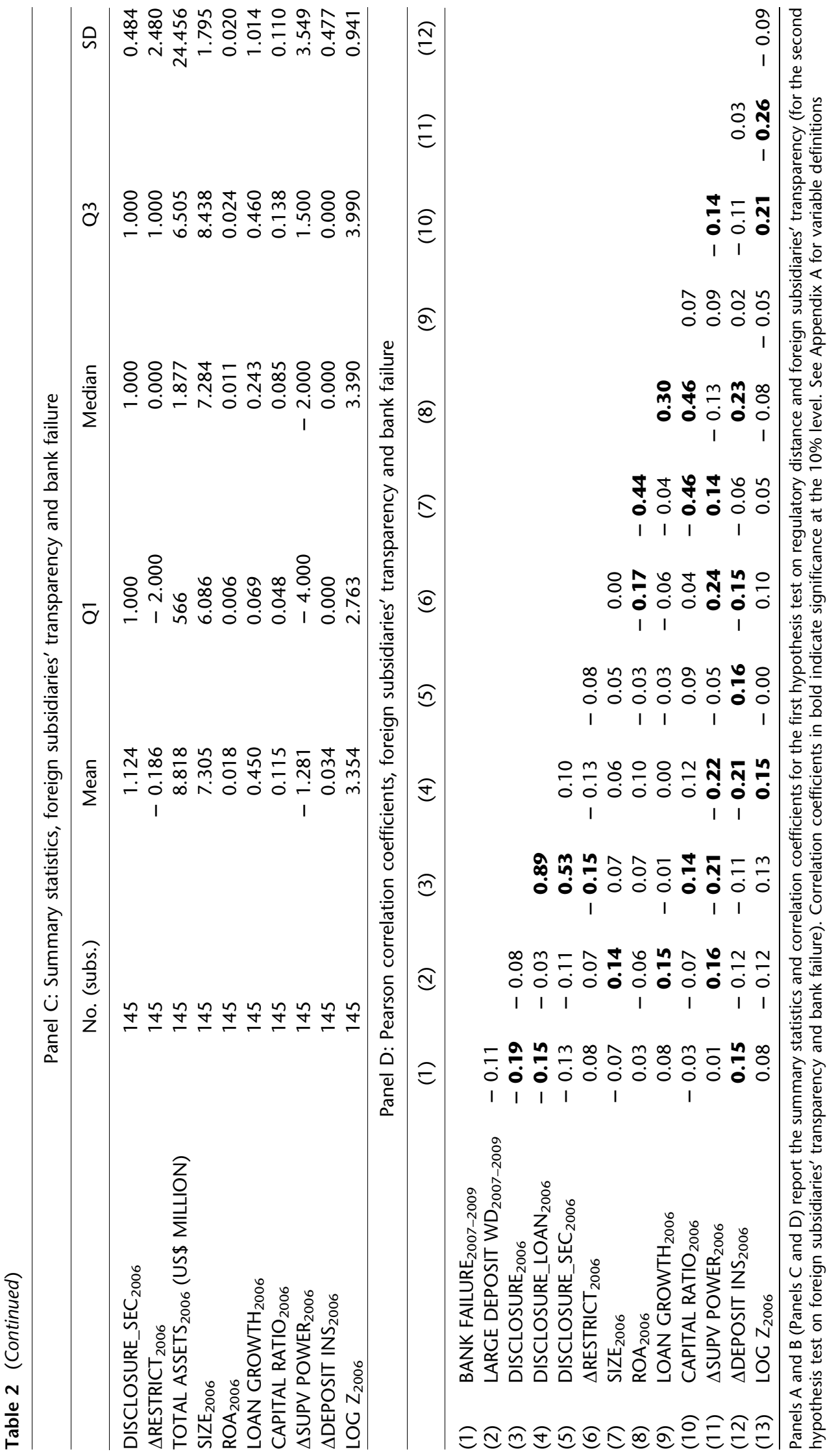


banking activities, we expect that banks have strong incentives to invest in non-banking activities when net interest margin is low and/or when the profits from non-banking activities is high. Thus, we use ENTRY BARRIER to proxy for decreasing net interest margin and employ GGO to capture the profitable opportunities from non-banking activities. In addition, while more restrictive home-country regulations can lead to greater regulatory distance (i.e., the IV is correlated with the endogenous regressor), the home-country ENTRY BARRIER and GGO are unlikely to have a first-order effect on subsidiary-level disclosure because subsidiaries are subject to host-country rather than home-country regulations (i.e., the exclusion restriction that the IV is uncorrelated with error terms).

We find that the coefficient on $\triangle$ RESTRICT remains significantly negative under the IV approach (coeff. $=-0.277 ; p=0.016$ ). We use the Hausman test to examine whether the regulatory distance is endogenous, where the null hypothesis is that the error terms is not correlated with regressors. To assess the validity of the instruments, we perform an $F$ test of the excluded exogenous variables in the first-stage regression, in which the null hypothesis is that the coefficient estimates of these variables are jointly equal to zero. We also test for overidentified restrictions, where the joint null hypothesis is that the instruments and the error term are uncorrelated. The last several rows of Column (3) report these statistics. The Hausman test is statistically significant $\left(\chi^{2}=6.048 ; p=0.015\right)$, indicating that the regulatory distance is endogenous. The first-stage $F$ statistic is 9.622 , close to the cutoff of 10 that indicates good instruments (Staiger \& Stock, 1997). The chi-squared statistic for Sargan's overidentification test, $1.234(p=$ 0.267 ), provides marginal support that our instruments are exogenous. Columns (4) and (5) of Table 3, Panel A, find that our results remain similar for DISCLOSURE_LOAN and DISCLOSURE_SEC.

Our results are robust to a variety of sensitivity tests. First, we repeat our analysis after excluding foreign subsidiaries from Germany, France, and the UK, i.e., the home countries of a large number of our sample foreign subsidiaries, as well as foreign subsidiaries located in Luxembourg, Switzerland, and the UK, i.e., the host countries of a large number of our sample foreign subsidiaries. Table 3, Panel B, shows that our results remain similar (Columns (1)-(6)). ${ }^{20}$ Second, we repeat our analysis after using the components of the regulatory distance index: $\triangle$ RESTRICT_SEC, $\triangle$ RESTRICT_INS, and $\triangle$ RESTRICT_REAL. Panel $\mathrm{C}$ shows that the restrictions on securities and real estate activities are the key factors shaping MNBs' financial reporting practices abroad (Columns (1)-(3)). Third, we use audit opinions as an alternative measure of bank transparency. Auditors' issuance of qualified audit opinions typically indicates deviations from GAAP or scope limitations, which alert investors and regulators of potential earnings manipulation (DeFond \& Zhang, 2014). If the restrictiveness of home-country regulations reduces foreign subsidiaries' transparency, we expect to observe a greater likelihood of qualified audit opinions for the foreign subsidiaries. The result confirms our expectation (Column (4)). ${ }^{21}$

Finally, in the internet appendix, we perform tests using alternative sample periods, subsamples conditional on bank size, additional controls on cross-country distances, and multilevel mixed-effects linear models. Overall, the results indicate that foreign subsidiaries have lower financial reporting transparency when their home countries have more restrictive regulations than their host countries.

\section{Foreign Subsidiaries' Transparency and Bank Failure}

To test our second hypothesis, we employ the 2007-2009 global financial crisis as an unexpected negative shock to banks' financial performance. Following prior studies (Kanagaretnam et al., 2014), we perform our test by regressing BANK FAILURE and LARGE DEPOSIT WD (measured over 20072009) on DISCLOSURE (measured in 2006). We further include control variables on bank performance and risk that are expected to influence bank failure, also measured in $2006 .{ }^{22}$ Eq. (2) includes entity-type fixed effects, $\delta$, to control for the types of the subsidiaries. Appendix A provides detailed definitions of variables. Our Probit regression model follows.

$$
\begin{aligned}
& \text { BANK FAILURE/LARGE DEPOSIT WD } \\
& \begin{aligned}
= & \beta_{0}+\beta_{1} \text { DISCLOSURE }+\beta_{2} \text { SIZE } \\
& +\beta_{3} \text { ROA }+\beta_{4} \text { LOAN GROWTH } \\
& +\beta_{5} \text { CAPITAL RATIO }+\beta_{6} \Delta \text { SUPV POWER } \\
& +\beta_{7} \Delta \text { DEPOSIT INS }+\beta_{8} \text { LOG Z }+\delta+\varepsilon .
\end{aligned}
\end{aligned}
$$




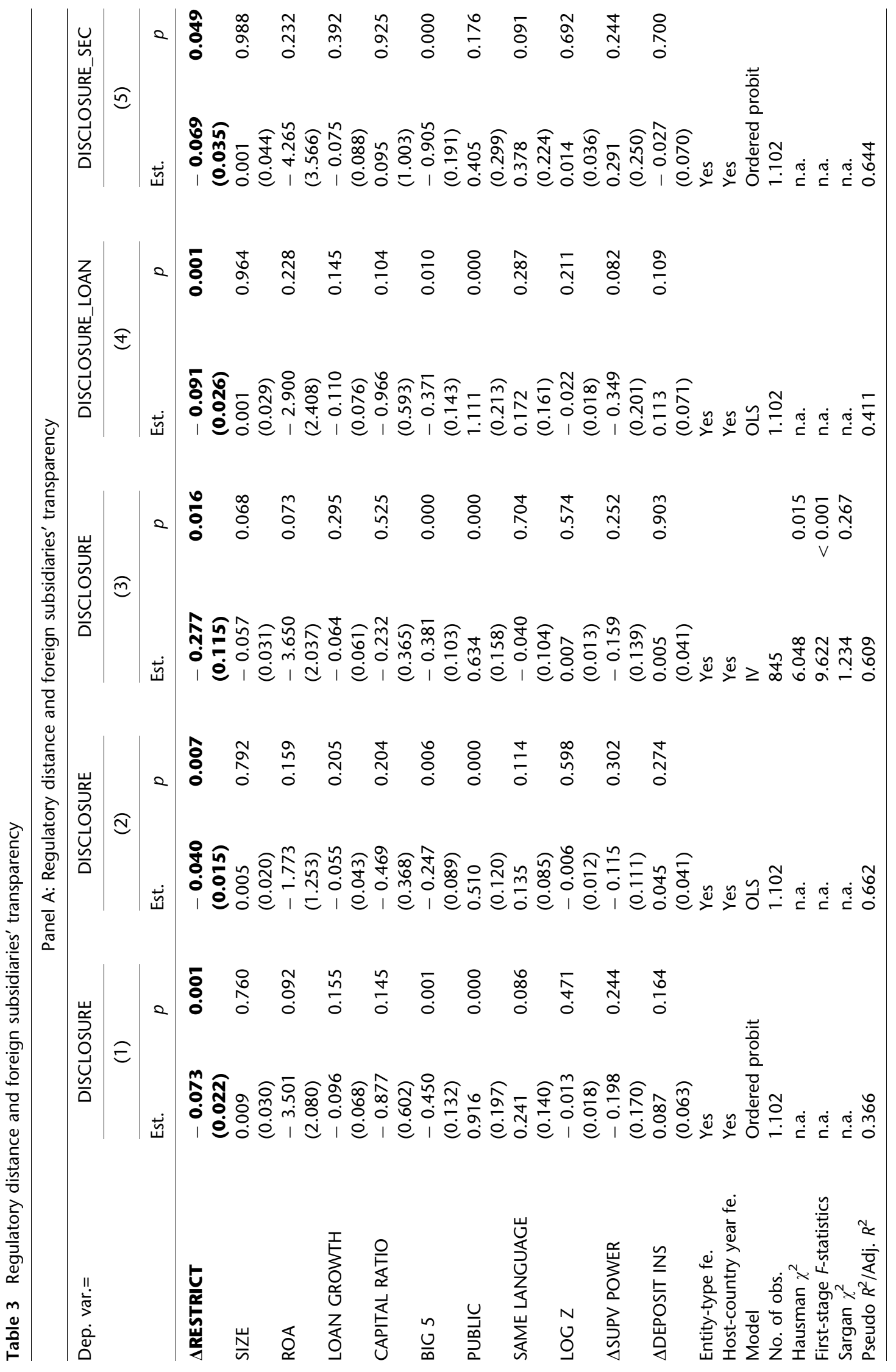




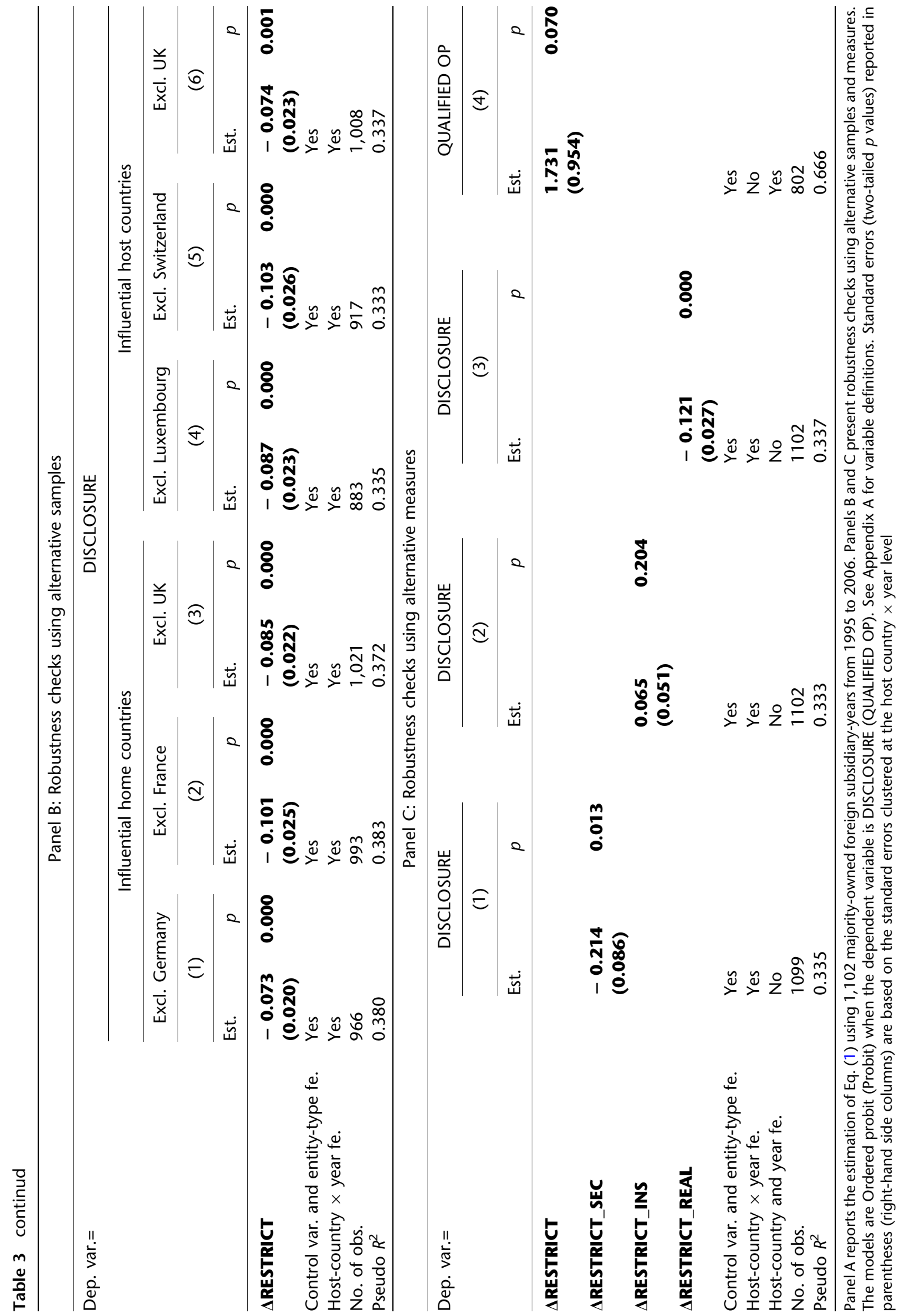


Our second hypothesis predicts $\beta_{1}$, the coefficient on DISCLOSURE, to be negative. Because each foreign subsidiary only appears once in this analysis, we cluster standard errors at the host-country level.

Panel A of Table 4 reports the results. Column (1) shows that the coefficient on DISCLOSURE is significantly negative (coeff. $=-0.500 ; p<0.001$ ), suggesting that foreign subsidiaries with lower transparency are more likely to fail during the financial crisis. In terms of economic significance, a one standard deviation decrease (increase) of DISCLOSURE from the mean increases (decreases) the probability of failure from $2.93 \%$ to $8.82 \%$ (from $2.93 \%$ to $0.75 \%$ ) when all other variables equal their means. The coefficient on SIZE is significantly negative, consistent with the view that government support reduces the likelihood of failure among large banks. The coefficients on CAPITAL RATIO and LOG $\mathrm{Z}$ are insignificant. One possible explanation is that these measures are not good predictors of subsidiaries' failure, because subsidiaries' equity capital may come from their parent bank's debt capital, which in turn increases the parent's risktaking incentives.

Columns (2) and (3) use the disclosure subindexes, DISCLOSURE_LOAN and DISCLOSURE_SEC. The results remain qualitatively similar. Because DISCLOSURE is a function of $\triangle$ RESTRICT, we implement a two-stage regression model by using Ordered probit model to estimate Eq. (1) and Probit model to estimate Eq. (2). Column (4) shows that the coefficient on DISCLOSURE remains significantly negative (coeff. $=-1.006 ; p<0.001){ }^{23}$ We also employ matched sample analysis to assess the robustness of our findings. To construct the matched sample, we first assign banks to the treatment group if their financial reporting transparency (DISCLOSURE) is higher than the sample median during the pre-crisis period and assign the other banks to the control group. Next, we match each treatment bank with a control bank based on the quintiles of $\triangle$ RESTRICT and LOG $\mathrm{Z}$ in the precrisis period. Column (5) shows that the coefficient on DISCLOSURE is significantly negative (coeff. = $0.549 ; p<0.001$ ), confirming that foreign subsidiaries with similar levels of risk-taking and regulatory distance are more likely to fail during the crisis when they have lower transparency.

Table 4, Panel B, reports the results for large deposit withdrawal. Columns (1)-(3) show that the coefficients remain significantly negative on DISCLOSURE (coeff. $=-0.178 ; p=0.086$ ) and
DISCLOSURE_SEC (coeff. $=-0.715 ; p=0.008$ ), but becomes insignificant on DISCLOSURE_LOAN (coeff. $=-0.108 ; p=0.409$ ). The evidence that loan disclosure has an insignificant effect on large deposit withdrawals but a significantly negative effect on the probability of bank failures suggests that the opacity of loan disclosure is primarily associated with more adverse outcome of foreign subsidiaries' bank failure. Using the two-stage estimation, Column (4) shows that the coefficient on DISCLOSURE is insignificant (coeff. $=-0.875 ; p=$ 0.173 ), likely due to the weakened test power after excluding failed banks from our sample. Finally, Column (5) shows that the coefficient on DISCLOSURE remains significantly negative (coeff. = $0.262 ; p=0.025)$ using the matched sample. Taken together, the findings support our hypothesis that foreign subsidiaries' diminished transparency increases the likelihood of bank failure.

\section{ADDITIONAL ANALYSES}

\section{Difference-in-Differences Analyses}

The association between regulatory distance and bank transparency abroad likely suffers from endogeneity in three dimensions: (1) correlated omitted variables in terms of local economic or regulatory environments, (2) correlated omitted variables in terms of bank-specific factors or self-selection bias, and (3) reverse causality. By including time-varying host-country fixed effects, our main analyses mitigate the first concern and ensure that the identification of our results comes from cross-sectional variation in transparency within a host-countryyear. We address the second concern by including various controls in Eq. (1) and implementing an IV estimation. In this section, we further use difference-in-differences approaches to tackle the endogeneity challenge.

Our first analysis examines whether foreign subsidiaries' transparency decreases after their home countries adopt reforms that restrict more bank activities. We focus on France, Germany, and the UK, which pursued well-identified post-crisis reforms to shield depositors' assets from bank risks (Lehmann, 2016) and are home to many of our sample foreign subsidiaries. In 2013, France and Germany adopted regulations to prevent banks from certain types of risky transactions by limiting proprietary trading and investments in hedge funds and other leveraged investment funds. Also in 2013, the UK passed the Ring-Fencing Regulation 
Table 4 Foreign subsidiaries' transparency and bank failure

Panel A: Foreign subsidiaries' pre-crisis transparency and likelihood of failures during the crisis

\begin{tabular}{|c|c|c|c|c|c|c|c|c|c|c|}
\hline & \multicolumn{10}{|c|}{ Dep. var.= Bank failure $2007-2009$} \\
\hline & \multicolumn{8}{|c|}{ Full sample } & \multirow{2}{*}{\multicolumn{2}{|c|}{$\frac{\text { Matched sample }}{(5)}$}} \\
\hline & \multicolumn{2}{|c|}{ (1) } & \multicolumn{2}{|c|}{$(2)$} & \multicolumn{2}{|c|}{ (3) } & \multicolumn{2}{|l|}{ (4) } & & \\
\hline & Est. & $p$ & Est. & $p$ & Est. & $p$ & Est. & $p$ & Est. & $p$ \\
\hline DISCLOSURE $_{2006}$ & $\begin{array}{l}-0.500 \\
(0.130)\end{array}$ & 0.000 & & & & & $\begin{array}{l}-1.006 \\
(0.126)\end{array}$ & 0.000 & $\begin{array}{l}-0.549 \\
(0.143)\end{array}$ & 0.000 \\
\hline DISCLOSURE_LOAN 2006 & & & $\begin{array}{l}-0.533 \\
(0.146)\end{array}$ & 0.000 & & & & & & \\
\hline DISCLOSURE_SEC 2006 & & & & & $\begin{array}{l}-0.803 \\
(0.272)\end{array}$ & 0.003 & & & & \\
\hline$\Delta$ RESTRICT $_{2006}$ & & & & & & & & & & \\
\hline $\mathrm{SIZE}_{2006}$ & $\begin{array}{l}-0.132 \\
(0.071)\end{array}$ & 0.061 & $\begin{array}{l}-0.140 \\
(0.066)\end{array}$ & 0.032 & $\begin{array}{l}-0.153 \\
(0.072)\end{array}$ & 0.035 & $\begin{array}{l}0.108 \\
(0.076)\end{array}$ & 0.155 & $\begin{array}{l}-0.143 \\
(0.111)\end{array}$ & 0.196 \\
\hline $\mathrm{ROA}_{2006}$ & $\begin{array}{l}-11.443 \\
(12.034)\end{array}$ & 0.342 & $\begin{array}{l}-9.673 \\
(12.621)\end{array}$ & 0.443 & $\begin{array}{l}-16.571 \\
(11.434)\end{array}$ & 0.147 & $\begin{array}{l}4.966 \\
(5.392)\end{array}$ & 0.357 & $\begin{array}{l}-13.238 \\
(17.090)\end{array}$ & 0.439 \\
\hline LOAN GROWTH ${ }_{2006}$ & $\begin{array}{l}-1.475 \\
(0.359)\end{array}$ & 0.000 & $\begin{array}{l}-1.564 \\
(0.408)\end{array}$ & 0.000 & $\begin{array}{l}-1.106 \\
(0.267)\end{array}$ & 0.000 & $\begin{array}{l}-0.009 \\
(0.093)\end{array}$ & 0.926 & $\begin{array}{l}-0.837 \\
(0.330)\end{array}$ & 0.011 \\
\hline CAPITAL RATIO 2006 & $\begin{array}{l}-1.321 \\
(2.265)\end{array}$ & 0.560 & $\begin{array}{l}-1.591 \\
(2.459)\end{array}$ & 0.518 & $\begin{array}{l}-0.815 \\
(1.668)\end{array}$ & 0.625 & $\begin{array}{l}1.257 \\
(1.147)\end{array}$ & 0.273 & $\begin{array}{l}-0.299 \\
(3.344)\end{array}$ & 0.929 \\
\hline$\triangle S U P V ~ P O W E R_{2006}$ & $\begin{array}{l}-0.026 \\
(0.040)\end{array}$ & 0.516 & $\begin{array}{l}-0.026 \\
(0.040)\end{array}$ & 0.519 & $\begin{array}{l}-0.000 \\
(0.040)\end{array}$ & 0.998 & $\begin{array}{l}-0.059 \\
(0.025)\end{array}$ & 0.018 & $\begin{array}{l}-0.008 \\
(0.053)\end{array}$ & 0.885 \\
\hline$\Delta$ DEPOSIT INS 2006 & $\begin{array}{l}0.472 \\
(0.326)\end{array}$ & 0.147 & $\begin{array}{l}0.395 \\
(0.325)\end{array}$ & 0.224 & $\begin{array}{l}0.694 \\
(0.299)\end{array}$ & 0.020 & $\begin{array}{l}-0.175 \\
(0.202)\end{array}$ & 0.387 & $\begin{array}{l}0.423 \\
(0.376)\end{array}$ & 0.261 \\
\hline LOG Z 2006 & $\begin{array}{l}0.378 \\
(0.232)\end{array}$ & 0.103 & $\begin{array}{l}0.389 \\
(0.215)\end{array}$ & 0.071 & $\begin{array}{l}0.250 \\
(0.237)\end{array}$ & 0.292 & $\begin{array}{l}0.072 \\
(0.129)\end{array}$ & 0.576 & $\begin{array}{l}0.241 \\
(0.298)\end{array}$ & 0.419 \\
\hline Entity-type fe. & Yes & & Yes & & Yes & & No & & Yes & \\
\hline Model & Probit & & Probit & & Probit & & Second-stage Probit & & Probit & \\
\hline No. of obs. & 145 & & 145 & & 145 & & 145 & & 123 & \\
\hline Pseudo $R^{2}$ & 0.289 & & 0.279 & & 0.238 & & 0.898 & & 0.305 & \\
\hline
\end{tabular}

Panel B: Foreign subsidiaries' pre-crisis transparency and likelihood of large deposit withdrawals during the crisis

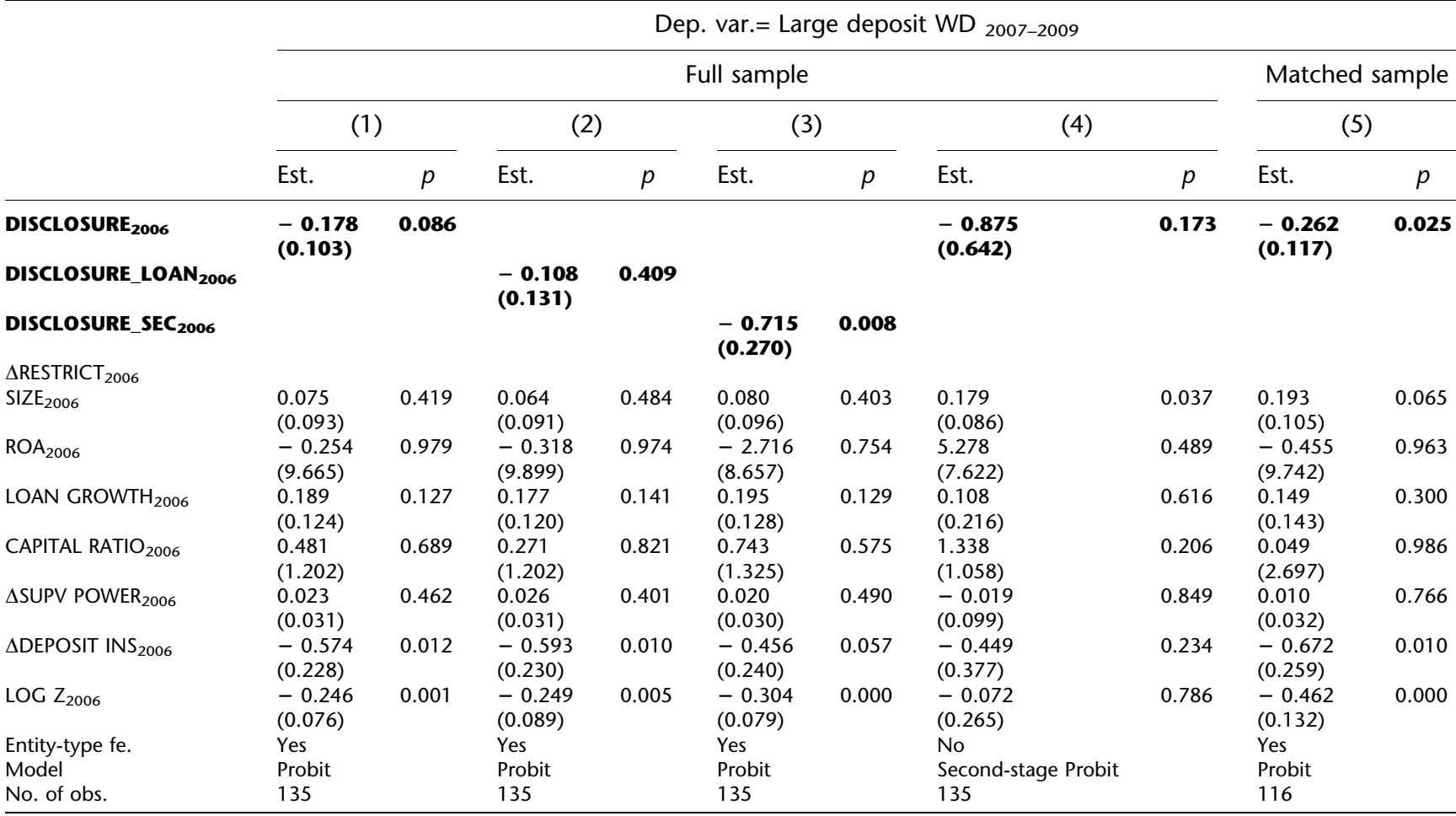


Table 4 (Continued)

Panel B: Foreign subsidiaries' pre-crisis transparency and likelihood of large deposit withdrawals during the crisis

\begin{tabular}{|c|c|c|c|c|c|c|c|c|c|c|}
\hline & \multicolumn{10}{|c|}{ Dep. var.= Large deposit WD $2007-2009$} \\
\hline & \multicolumn{8}{|c|}{ Full sample } & \multirow{2}{*}{\multicolumn{2}{|c|}{$\frac{\text { Matched sample }}{(5)}$}} \\
\hline & \multicolumn{2}{|c|}{ (1) } & \multicolumn{2}{|c|}{ (2) } & \multicolumn{2}{|c|}{ (3) } & \multicolumn{2}{|c|}{ (4) } & & \\
\hline & Est. & $p$ & Est. & $p$ & Est. & $p$ & Est. & $p$ & Est. & $p$ \\
\hline Pseudo $R^{2}$ & 0.090 & & 0.081 & & 0.102 & & 0.598 & & 0.152 & \\
\hline
\end{tabular}

Reports the regression results of foreign subsidiaries' transparency and their failures during the 2007-2009 global financial crisis. Panel A presents the results for banks that do not survive the crisis and Panel B presents the results for large deposit withdrawals. See Appendix A for variable definitions. Standard errors (two-tailed $p$ values) reported in parentheses (right-hand side columns) are based on the standard errors clustered at the host-country level

that requires banks to use a separate entity for risky wholesale and investment banking activities. ${ }^{24}$ Table 5, Panel A, describes these regulations.

The sample for this test comprises 32 foreign subsidiaries (owned by 24 parent banks) as the treatment group and 39 foreign subsidiaries (owned by 32 parent banks) as the control group from 2011 to $2015 .^{25}$ The treatment sample consists of subsidiaries whose parent banks are located in France, Germany, or the UK. While we identify the treatment sample through regulatory reforms rather than changes in the activity restrictions index (because it is unclear in which year the changes take place), we use the World Bank surveys to construct our control sample, because they allow us to identify countries that do not experience changes in the indexes. ${ }^{26}$ We regress DISCLOSURE on a dummy variable indicating the post-adoption period, 2013-2015 (POST), a dummy variable indicating the treatment sample (TREAT), their interaction term, and the same control variables and fixed effects, as in Eq. (1).

Table 5, Panel B, reports the results. Column (1) shows that the coefficient on POST $\times$ TREAT is significantly negative (coeff. $=-1.518 ; p=0.038$ ), indicating that, when home countries adopt more restrictive regulations, the foreign subsidiaries subsequently experience a decrease in transparency. Column (2) excludes the adoption year and finds similar results. Column (3) uses a timing approach that replaces POST with three indicator variables: YEAR - 1 and YEAR 0 for the year prior to and during the adoption, and YEAR 1+, for the post-adoption period (Bertrand \& Mullainathan, 2003). The coefficients on YEAR $-1 \times$ TREAT (coeff. $=-1.092 ; p=$ 0.304 ) and YEAR $0 \times$ TREAT (coeff. $=-1.187 ; p=$ 0.198 ) are insignificant, suggesting no difference in trends between treatment and control groups before the reforms. Further, the coefficient on
YEAR $1+\times$ TREAT is significantly negative (coeff. $=-2.865 ; p=0.005)$, suggesting that the reduced bank transparency materializes after home countries adopt more restrictive regulations. In sum, while the post-financial-crisis regulations do not measure regulatory distance in the same way as the baseline model, this analysis provides a cleaner identification and corroborates our inference that more restrictive regulations at home decrease bank transparency abroad.

Our second analysis takes advantage of crossborder acquisitions. We expect that subsidiaries would experience a decrease in transparency when they are acquired by banks from countries with more restrictive regulations. We build the sample by using financial statement data from Bankscope during 1995-2015 and cross-border acquisition data that involve majority-control deals ending in 2014 from Zephyr. ${ }^{27}$ The final sample for this analysis comprises 1,502 subsidiary-years based on 163 deals from 38 acquirer countries and 39 target countries.

Table 6, Panel A, presents univariate analysis comparing the disclosure between treatment and control groups in the year before acquisition, where the control group consists of all the other subsidiaries from the same host-country-year as the target subsidiaries. We find that target subsidiaries have higher disclosures than the control group (3.772 vs. 3.010). Panel B shows that targets' disclosure levels increase from 3.091 to 4.351 after being acquired. These results suggest that target subsidiaries on average have higher transparency, compared with other subsidiaries in the same host country, and they continue to experience an increase in transparency after acquisition.

We regress DISCLOSURE on a dummy variable indicating post-acquisition period (POST), a variable measuring the regulatory distance between the 
Table 5 The effect of home-country banking reforms on foreign subsidiaries' transparency

Panel A: Description of major banking reforms that constrain bank risk-taking

\begin{tabular}{llll}
\hline Country & Year & Regulation & Description \\
\hline France & 2013 & $\begin{array}{l}\text { French law no. } \\
2013-672 \\
\text { Bank Separation } \\
\text { Germany }\end{array}$ & $\begin{array}{l}\text { Separate banking activities; limit proprietary trading and investments in hedge funds and } \\
\text { other leveraged investment funds. } \\
\text { Ring-fence the deposit and lending business of major institutions against certain types of risky } \\
\text { transactions. }\end{array}$ \\
UK & 2013 & $\begin{array}{l}\text { Financial Services } \\
\text { Act }\end{array}$ & $\begin{array}{l}\text { Ring-fence retail and small and medium-sized enterprise and deposit-taking businesses in legal } \\
\text { entities which are separate to, and financially independent from, those entities undertaking } \\
\text { riskier, wholesale and investment banking activities }\end{array}$ \\
\hline
\end{tabular}

Panel B: Regression analysis, ordered probit model

\begin{tabular}{|c|c|c|c|c|c|c|}
\hline & \multicolumn{6}{|c|}{ Dep. var.= Disclosure } \\
\hline & \multirow{2}{*}{\multicolumn{2}{|c|}{$\begin{array}{c}\text { Full sample } \\
(1)\end{array}$}} & \multirow{2}{*}{\multicolumn{2}{|c|}{$\frac{\text { Excl. adoption year }}{(2)}$}} & \multirow{2}{*}{\multicolumn{2}{|c|}{$\frac{\text { Timing approach }}{(3)}$}} \\
\hline & & & & & & \\
\hline & Est. & $p$ & Est. & $p$ & Est. & $p$ \\
\hline POST & $\begin{array}{l}7.669 \\
(2.195)\end{array}$ & 0.000 & $\begin{array}{l}7.425 \\
(2.442)\end{array}$ & 0.002 & & \\
\hline TREAT & $\begin{array}{l}-1.928 \\
(1.166)\end{array}$ & 0.098 & $\begin{array}{l}-1.952 \\
(1.186)\end{array}$ & 0.100 & $\begin{array}{l}-1.558 \\
(1.307)\end{array}$ & 0.233 \\
\hline POST $\times$ TREAT & $\begin{array}{l}-1.518 \\
(0.730)\end{array}$ & 0.038 & $\begin{array}{l}-2.718 \\
(0.780)\end{array}$ & 0.000 & & \\
\hline YEAR - 1 & & & & & $\begin{array}{l}4.701 \\
(2.012)\end{array}$ & 0.019 \\
\hline YEAR 0 & & & & & $\begin{array}{l}9.595 \\
(2.488)\end{array}$ & 0.000 \\
\hline YEAR 1+ & & & & & $\begin{array}{l}8.092 \\
(2.181)\end{array}$ & 0.000 \\
\hline YEAR $-1 \times$ TREAT & & & & & $\begin{array}{l}-1.092 \\
(1.062)\end{array}$ & 0.304 \\
\hline YEAR $0 \times$ TREAT & & & & & $\begin{array}{l}-1.187 \\
(0.923)\end{array}$ & 0.198 \\
\hline YEAR $1+\times$ TREAT & & & & & $\begin{array}{l}-2.865 \\
(1.028)\end{array}$ & 0.005 \\
\hline Control variables, Entity-type fe., Host-country $\times$ year fe. & Yes & & Yes & & Yes & \\
\hline No. of treatment/control parent banks & $14 / 36$ & & $14 / 36$ & & $14 / 36$ & \\
\hline No. of treatment/control subsidiaries & $27 / 46$ & & $27 / 46$ & & $27 / 46$ & \\
\hline No. of obs. & 564 & & 421 & & 564 & \\
\hline Pseudo $R^{2}$ & 0.641 & & 0.660 & & 0.646 & \\
\hline
\end{tabular}

Reports the results of the effect of major post-crisis banking reforms on foreign subsidiaries' transparency. Panel A describes the regulatory reforms. Panel B reports the difference-in-differences analysis from 2011 to 2015. POST is an indicator variable equal to one for the post-adoption period, 2013-2015. TREAT is an indicator variable equal to one for banks with the parent headquartered in France, Germany, and the UK. See Appendix A for the definitions of other variables. Standard errors (two-tailed $p$ values) reported in parentheses (right-hand side columns) are based on the standard errors clustered at the host country $\times$ year level 
Table 6 Bank acquisitions, regulatory distance, and transparency

Panel A: M\&A target subsidiaries versus other subsidiaries in the year before acquisition

\begin{tabular}{|c|c|c|c|c|c|c|c|}
\hline \multirow[b]{2}{*}{ Variable } & \multicolumn{3}{|c|}{ Target subs., year before acquisition } & \multicolumn{2}{|c|}{ Other subs. in the same host-country-year } & \multirow[t]{2}{*}{ Diff. in mean (target-others) } & \multirow[t]{2}{*}{$p$} \\
\hline & Mean & & Median & Mean & Median & & \\
\hline Disclosure & 3.772 & & 3.000 & 3.010 & 3.000 & 0.761 & 0.000 \\
\hline \multicolumn{8}{|c|}{ Panel B: Changes in subsidiaries' transparency following the acquisition } \\
\hline & & \multicolumn{2}{|c|}{ Post-acquisition } & \multicolumn{2}{|c|}{ Pre-acquisition } & \multirow[t]{2}{*}{ Diff. in Mean (Post-pre) } & \multirow[t]{2}{*}{$p$} \\
\hline Variable & & Mean & Median & Mean & Median & & \\
\hline Disclosure & & 4.351 & 4.000 & 3.091 & 3.000 & 260 & 0.000 \\
\hline
\end{tabular}

Panel C: Regression analysis, ordered probit model

\begin{tabular}{|c|c|c|c|c|c|c|}
\hline & \multicolumn{6}{|c|}{ Dep. var. = Disclosure } \\
\hline & \multirow{2}{*}{\multicolumn{2}{|c|}{$\begin{array}{c}\text { Full sample } \\
(1)\end{array}$}} & \multirow{2}{*}{\multicolumn{2}{|c|}{$\frac{\text { Excl. event year }}{(2)}$}} & \multirow{2}{*}{\multicolumn{2}{|c|}{$\begin{array}{c}\text { Timing approach } \\
\text { (3) }\end{array}$}} \\
\hline & & & & & & \\
\hline & Est. & $p$ & Est. & $p$ & Est. & $p$ \\
\hline POST & $\begin{array}{l}0.067 \\
(0.150)\end{array}$ & 0.657 & $\begin{array}{l}0.047 \\
(0.167)\end{array}$ & 0.779 & & \\
\hline$\triangle \mathrm{RESTRICT}$ & $\begin{array}{l}-0.004 \\
(0.042)\end{array}$ & 0.924 & $\begin{array}{l}0.010 \\
(0.044)\end{array}$ & 0.814 & $\begin{array}{l}0.004 \\
(0.046)\end{array}$ & 0.930 \\
\hline POST $\times \triangle \mathrm{RESTRICT}$ & $\begin{array}{l}-0.122 \\
(0.066)\end{array}$ & 0.062 & $\begin{array}{l}-0.159 \\
(0.070)\end{array}$ & 0.024 & & \\
\hline YEAR - 1 & & & & & $\begin{array}{l}-0.001 \\
(0.213)\end{array}$ & 0.996 \\
\hline YEAR 0 & & & & & $\begin{array}{l}-0.019 \\
(0.257)\end{array}$ & 0.941 \\
\hline YEAR 1+ & & & & & $\begin{array}{l}0.104 \\
(0.162)\end{array}$ & 0.519 \\
\hline YEAR $-1 \times \Delta$ RESTRICT & & & & & $\begin{array}{l}-0.014 \\
(0.093)\end{array}$ & 0.882 \\
\hline YEAR $0 \times \Delta$ RESTRICT & & & & & $\begin{array}{l}0.074 \\
(0.113)\end{array}$ & 0.514 \\
\hline YEAR $1+\times \Delta$ RESTRICT & & & & & $\begin{array}{l}-0.150 \\
(0.072)\end{array}$ & 0.036 \\
\hline $\begin{array}{l}\text { Control variables, Deal payment control, } \\
\text { Entity-type fe., Host-country } \times \text { year fe. }\end{array}$ & Yes & & Yes & & Yes & \\
\hline No. of deals & 163 & & 163 & & 163 & \\
\hline No. of acquirer/target countries & $38 / 39$ & & $38 / 39$ & & $38 / 39$ & \\
\hline No. of acquirer/target banks & $112 / 145$ & & $112 / 145$ & & $112 / 145$ & \\
\hline No. of obs. & 1,502 & & 1,432 & & 1,502 & \\
\hline Pseudo $R^{2}$ & 0.552 & & 0.564 & & 0.554 & \\
\hline
\end{tabular}

Reports the effect of the regulatory distance between acquirer and target countries on target banks' transparency. Panel A presents the comparison of the disclosure between treatment and control groups in the year before acquisition. Panel B reports changes in target banks' disclosure following the acquisitions. Panel C reports the difference-in-differences analysis during 1995-2015. See Appendix A for variable definitions. Standard errors (twotailed $p$ values) reported in parentheses (right-hand side columns) are based on the standard errors clustered at the host country $\times$ year level 
Table 7 Mechanisms through which regulatory distance affects bank transparency

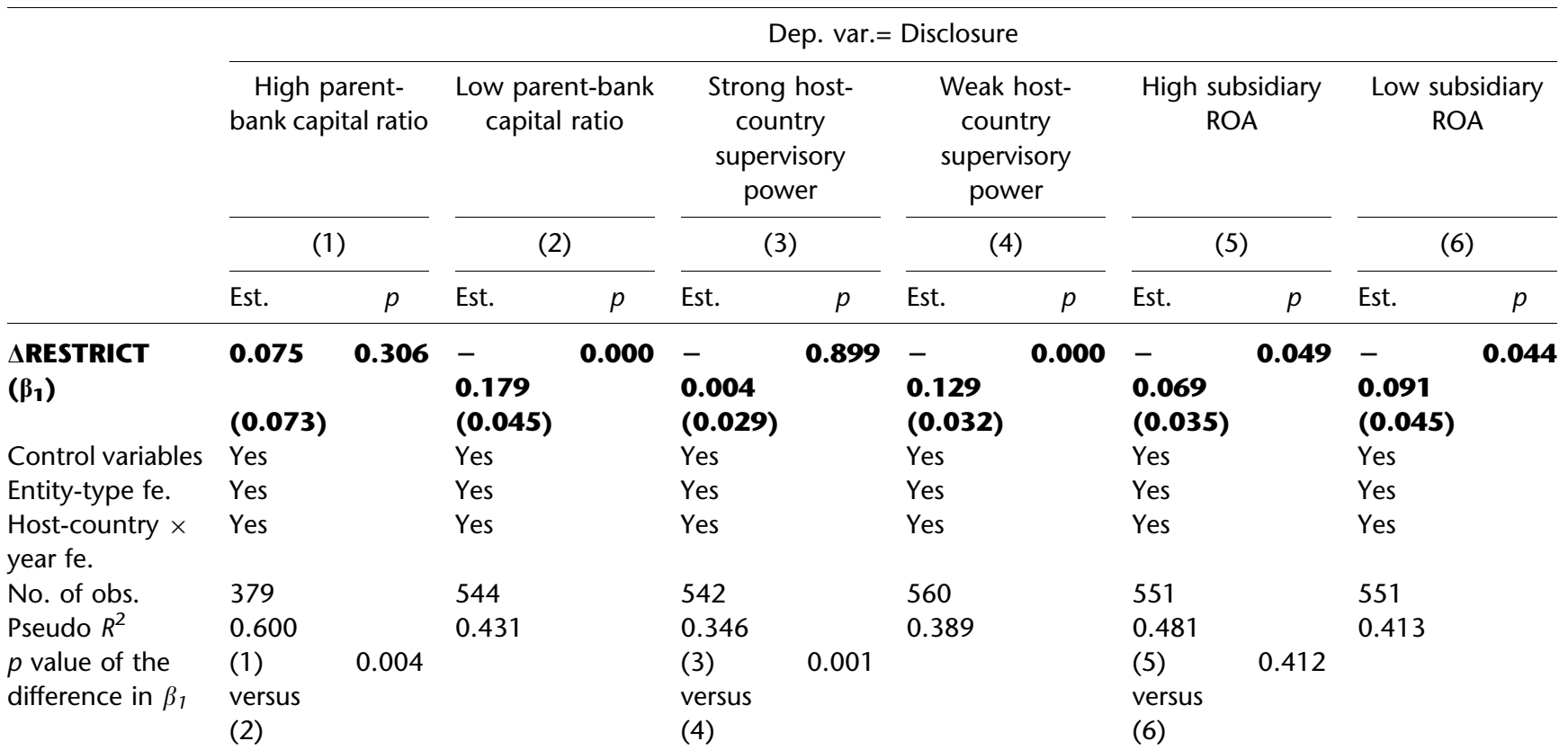

Reports the results of regulatory distance and foreign subsidiaries' transparency, conditional on parent-bank capital ratios, host-country supervisory power, and foreign subsidiaries' profitability, using a sample during 1995-2006. Columns (1) and (2) report the results conditional on parent-bank capital ratios. Columns (3) and (4) report the results conditional on host-country supervisory power. Columns (5) and (6) report the results conditional on foreign subsidiaries' ROA. The models are Ordered probit. See Appendix A for variable definitions. Standard errors (two-tailed $p$ values) reported in parentheses (right-hand side columns) are based on the standard errors clustered at the host country $\times$ year level

country of the acquirer bank and the country of the target bank ( $\triangle$ RESTRICT), their interaction term, and the same control variables and fixed effects, as in Eq. (1). We also include deal payment fixed effects to control for the factors that drive the method of payment choice (Harford, Klasa, \& Walcott, 2009). Table 6, Panel C, reports the results. Column (1) shows that coefficient on POST is insignificant (coeff. $=0.067 ; p=0.657$ ), suggesting that subsidiaries experience no change in transparency when they are acquired by banks from countries with the same level of activity restrictions. The coefficient on $\triangle$ RESTRICT is also insignificant (coeff. $=-0.004 ; p=0.924$ ), suggesting that, prior to the acquisition, there is no difference in transparency between subsidiaries that are acquired by banks from countries with lax activity restrictions versus those from countries with tight restrictions. Importantly, the coefficient on POST $\times$ $\triangle$ RESTRICT is significantly negative (coeff. = $0.122 ; p=0.062$ ). This result suggests that subsidiaries' transparency decreases after being acquired by banks from countries with greater activity restrictions. The results hold when we exclude the event year to mitigate the confounding effects of acquisition (Column (2)). Column (3) replaces POST with three indicator variables: YEAR
-1 and YEAR 0 for the year prior to and during the acquisition, and YEAR 1+ for the post-acquisition period. The results suggest that transparency among targets acquired by banks with tighter or weaker activity restrictions is similar prior to the acquisitions and that the predicted effect of regulatory distance on subsidiaries' transparency materializes after acquisition.

Finally, we perform analysis using foreign branches from the same home country as the benchmark. As reported in the internet appendix, we find that, relative to foreign branches, foreign subsidiaries' transparency decreases when their home countries have tighter regulations than their host countries.

\section{Analysis of the Mechanisms}

To examine the role of agency conflicts and regulatory environments, we perform analyses conditional on parent banks' capital ratios and the host country's supervisory power. Because risk-taking incentives that arise from debt-equity conflicts are stronger when parent banks have higher leverage, this explanation predicts a more negative relationship between disclosure and regulatory distance when the parent banks have lower capital ratios. ${ }^{28}$ It also predicts a more negative relationship when 
the foreign subsidiaries are located in host countries with weaker supervision, because strong hostcountry supervisory power should reduce parent banks' ability to take excessive risk. To examine the role of proprietary costs, we perform analyses conditional on profitability. The proprietary cost explanation predicts a more negative relationship between disclosure and regulatory distance among foreign subsidiaries with higher profitability.

We partition our sample based on the sample median of parent banks' capital ratios, host-country supervisory power, and foreign subsidiaries' profitability, then re-estimate Eq. (1) for each subsample. Table 7 presents the results. Columns (1) and (2) show that the coefficient on $\triangle$ RESTRICT is significant only when the foreign subsidiaries are controlled by parent banks with low capital ratios (coeff. $=-0.179 ; p<0.001$ ), and the difference between the subsamples is significant $(p=0.004){ }^{29}$ Columns (3) and (4) show that this coefficient is significant only among foreign subsidiaries in the host countries with weak supervisory power (coeff. $=-0.129 ; p<0.001$ ), and the difference between the subsamples is also significant $(p=0.001)$. Columns (5) and (6) show that this is significant in both the subsamples of high and low ROA, and the difference is insignificant $(p=0.412)$. These findings suggest that debt-equity agency conflicts and regulatory environments shape the disclosure practices of foreign subsidiaries.

\section{CONCLUSIONS}

We find that bank transparency declines when home countries have tighter activity restrictions than host countries, and the result is more pronounced for foreign subsidiaries controlled by parent banks with low capital ratios or located in host countries with weak supervision. Foreign subsidiaries are also more likely to fail during the 2007-2009 financial crisis when they have more opaque financial reporting right before the crisis. Our results are consistent with the view that the opacity of MNBs' reporting, which stems from debtequity agency conflicts with weak regulation, exacerbates bank failures abroad.

Our study advances international business research by integrating debt-equity agency conflicts and institutional arrangements into headquarterssubsidiary relationships. As multinationals have become dominant global players, their behavior across regulatory environments constitutes a promising research avenue. Future research might explore multinationals' information environments by taking a closer look at their subsidiary-level financial statement information to offer insights beyond reporting transparency and headquarterssubsidiary relationships.

\section{ACKNOWLEDGMENTS}

We thank the following for their helpful comments: Davlat Abduvali (discussant), Patricia Dechow, Yupeng Lin (discussant), David Lucca, Lemma Senbet (the Editor), two anonymous referees, and workshop participants at the 2017 AAA Annual meeting, 2017 AAA Doctoral consortium, 2018 ABFER Conference, the 10th NCTU International Finance Conference, 2017 University of Michigan Accounting Kapnick Spring Conference, 2018 Virginia Accounting Research Conference, Georgetown University, Hong Kong University of Science and Technology, National Cheng-Chi University, and Tsinghua University. We thank Stephan Siegel for providing the global growth opportunities data and Roope Keloharju for excellent research assistance. An earlier version of this paper was circulated under the title "Regulatory Arbitrage and Bank Financial Reporting Quality Abroad." The work described in this paper was supported by Project no. IEMS17BM02 funded by the HKUST Institute for Emerging Market Studies.

\section{NOTES}

${ }^{1}$ As an example of the importance of these activities, in 2013, France and Germany adopted regulations that prevent banks from certain types of risky transactions, and the U.K. passed rules that require banks to separate core retail banking from investment banking.

${ }^{2}$ Karolyi and Taboada (2015, footnote 8) state "by acquiring banks in countries with fewer restrictions on bank activities, acquirers may engage in activities prohibited in the home country."

${ }^{3}$ According to IMF (2014b), 145 banks globally account for 85 percent of the assets of the world's top 1,000 banks in 2008. The top five largest crossborder banking groups have $\$ 10$ trillion of assets in total and over 50 percent of their credit risk exposures outside their home countries, with subsidiaries in more than 60 countries.

${ }^{4}$ Increased risk-taking abroad may include lending to risky firms, or engaging in risky securities or real estate activities, which can increase 
shareholders value and preserve debtholder or other stakeholder value, or increase shareholder value but decrease debtholder or other stakeholder value.

${ }^{5}$ The Bankscope parent-subsidiary link table includes 6,620 subsidiaries with missing ownership data and 10,487 minority-owned subsidiaries. Most countries impose a threshold of 5\% of the firm's issued shares for disclosing ownership (Li, Moshirian, Pham, \& Zein, 2006). Because subsidiaries with missing ownership information are those below the required threshold and we focus on majorityowned subsidiaries, our results should be insensitive to cross-country differences in disclosure requirements.

${ }^{6}$ Bankscope includes two ownership variables: DATA9308 (Direct ownership\%) and DATA9309 (Total ownership\%). To illustrate, if Bank \#1 owns Bank \#2, and Bank \#2 in turn owns Bank \#3, the database will include two observations for Bank \#3 in its parent-subsidiary link table: (1) Bank \#1 (Parent) and Bank \#3 (Sub.), with valid values of Total ownership\% and missing value of Direct ownership\%, and (2) Bank \#2 (Parent) and Bank \#3 (Sub.), with valid values of both Total ownership\% and Direct ownership\%. By imposing this sample selection criterion, we drop the first observation, thereby ensuring a unique parent-subsidiary link for each subsidiary.

${ }^{7}$ The sample size is small in early years because Bankscope retains data for a rolling period of 16 years.

${ }^{8}$ The number of U.S. foreign subsidiaries in our sample is much smaller than the number reported by the Board of Governors of the Federal Reserve System, because most of the foreign subsidiaries owned by U.S. banking organizations are leasing and investment companies (Board of Governors of the Federal Reserve System, 1999: 605). To examine the effect of regulatory arbitrage on bank transparency abroad, we include only subsidiary banks.

${ }^{9}$ Barth et al. (2013) compile the data for 180 countries based on the four surveys sponsored by the World Bank in 1999, 2003, 2007, and 2011. Because our sample period spans from 1995 to 2009, we follow Karolyi and Taboada (2015) and use the index from Survey I (data as of 1999) for the period before 2001, the index from Survey II (data as of 2002) for the period 2002 to 2004, the index from Survey III (data as of 2005) for the period 2005 to 2009 .
${ }^{10}$ The U.S.'s regulatory approach to banks' noncore operations is distinct from other developed economies. The U.S. has a higher index due to the 1933 Glass-Steagall Act (which separates commercial and investment banking) and the 1956 Bank Holding Company Act (which prohibits bank holding companies from controlling almost all nonbanking firms). While the Glass-Steagall Act is repealed by the 1999 Gramm-Leach-Bliley Act, the Volcker Rule of the 2010 Dodd-Frank Act prohibits banks from certain investment activities.

${ }^{11}$ Bankscope is commonly used among banks to assess counterparties. The average interbank liability to total assets ratio is $21.42 \%$ in our sample.

${ }^{12}$ Because we include host country-year fixed effects throughout the regression models, our results reflect the reporting discretion by controlling for mandatory disclosure requirements in the host-country-year. To assess the reporting discretion, we construct DISCLOSURE_MEAN and DISCLOSURE_STD that measure the mean and standard deviation of DISCLOSURE within each host-country-year. The analysis (untabulated) finds that the mean of DISCLOSURE_MEAN and DISCLOSURE_STD is 2.9 and 0.5 , indicating that bank transparency exhibits considerable within-country variation.

${ }^{13}$ BANK FAILURE equals one if the bank: (1) exists in 2006, (2) stops providing financial statement information during 2007-2009, and (3) has an inactive status at Bankscope (e.g., "dissolved," "in liquidation," or "no longer with accounts on Bankscope"). Brown and Dinc (2011) suggest that most bank failures are in the form of government takeovers and license suspension or revocations, rather than bankruptcies.

${ }^{14}$ For example, public disclosure on one of the failed banks, BIPIELLE Bank (Suisse) SA, explicitly discusses the provision of deposit guarantee in its host country (https://thebanks.eu/banks/9702).

${ }^{15}$ Our additional analysis finds that the mean values of $\triangle$ RESTRICT_SEC, $\triangle$ RESTRICT_INS, and $\triangle$ RESTRICT_REAL are 0.094, 0.007, and 0.076, suggesting that securities and real estate are likely the main activities that are allowed in host countries but not in home countries. Later analysis in Table 3, Panel B, also confirms that the two activities are the ones that drive the disclosure opacity.

${ }^{16}$ Because the distribution is highly skewed, we measure bank size (SIZE) as the natural logarithm of total assets. 
${ }^{17}$ While the majority of the subsidiaries are audited by Big Five, the literature suggests that Big Five auditors are less likely to enforce higher reporting quality when the legal regime is weaker (Francis and Wang, 2008).

${ }^{18}$ Indicators for bank-entity types are based on Bankscope. Among our sample subsidiary banks, $67 \%$ are commercial banks and $8 \%$ are investment banks.

${ }^{19}$ Additional analysis (untabulated) finds that the coefficient on $\triangle$ SUPV POWER becomes significantly negative (coeff. $=-0.050 ; p<0.001$ ) after excluding host country-year fixed effects. This finding suggests that without controlling for host country-year fixed effects, bank transparency declines when the host country has weaker supervisory power than the home country. This finding is also consistent with the significantly negative correlation between DISCLOSURE and $\triangle$ SUPV POWER in Table 2, Panel B.

${ }^{20} \mathrm{We}$ also perform an additional test after restricting the sample to commercial banks and find the result (untabulated) remains qualitatively the same.

${ }^{21}$ We do not include entity-type and country-year fixed effects because the issuance of qualified audit opinions is rare and a model including these fixed effects cannot converge. Because some subsidiaries are unaudited, the number of observations for this test is slightly reduced. About 0.68 percent of the subsidiaries in our sample receive a qualified audit opinion. This low frequency is consistent with our expectation that qualified audit opinions are rare.

${ }^{22}$ We do not include host-country-year fixed effects, because a failure of a foreign subsidiary is rare and there is not enough variation within each host country during the crisis period.

${ }^{23}$ The two-stage regression model would not converge with inclusion of entity type fixed effects. We improve the odds of convergence by excluding entity type fixed effects and using STATA command "CMP" (Roodman, 2011).

\section{REFERENCES}

Barnea, A., Haugen, R., \& Senbet, L. 1985. Agency problems and financial contracting. New Jersey: Prentice Hall Foundations of Finance Series.

Barth, J. R., Caprio, G., \& Levine, R. 2013. Bank regulation and supervision in 180 countries from 1999-2011. Journal of Financial Economic Policy, 5(2): 111-219.

Baumann, U., \& Nier, E. 2004. Disclosure, volatility, and transparency: An empirical investigation into the value of bank disclosure. Federal Reserve Bank of New York Economic Policy Review, 10(2): 31-45.
${ }^{24}$ The European Commission released a proposal of banking structural reforms in 2014 following the Liikanen report (or "Report of the European Commission's High-level Expert Group on Bank Structural Reform") but withdrew the proposal in 2017. Many countries have other regulatory reforms after the financial crisis. Basel III also strengthens capital requirements and increases risk disclosure. To the extent that the other countries in the control group also have significant regulatory reforms, it would bias against finding the predicted results.

${ }^{25}$ The sample period ends in 2015 because Bankscope, owned by Bureau van Dijk, was replaced by BankFocus on January 1, 2017, which has different data coverage and structures.

${ }^{26} \mathrm{We}$ restrict the control sample to the subsidiaries that have no regulatory differences between home and host countries in both Surveys IV (data as of 2011) and V (data as of 2016) and whose parent banks are not located in France, Germany, and the U.K. We follow the same index construction approach by Barth et al. (2013) and use Survey V from the World Bank (2019) to update the activity restriction index as of 2016.

${ }^{27}$ We stop the acquisition data in 2014 to allow at least one year of post-acquisition financial statement data for our difference-in-differences analysis.

${ }^{28}$ We adjust parent banks' capital ratios by subtracting the average home country-year capital ratios to capture the risk-taking incentives beyond the limits imposed by home-country bank regulations.

${ }^{29}$ The sample size is slightly smaller in the test of parent banks' capital ratios, because, for some subsidiaries, we can identify home countries but not specific parent banks using the Bankscope parent-subsidiary link table.

Beatty, A., \& Liao, S. 2014. Financial accounting in the banking industry: A review of the empirical literature. Journal of Accounting and Economics, 58(2-3): 339-383.

Bekaert, G., Harvey, C. R., Lundblad, C., \& Siegel, S. 2007. Global growth opportunities and market integration. Journal of Finance, 62(3): 1081-1137.

Bertrand, M., \& Mullainathan, S. 2003. Enjoying the quiet life? Corporate governance and managerial preferences. Journal of Political Economy, 111(5): 1043-1075.

Beugelsdijk, S., Nell, P. C., \& Ambos, B. 2017. When do distance effects become empirically observable? An investigation in the 
context of headquarters value creation for subsidiaries. Journal of International Management, 23(3): 255-267.

Board of Governors of the Federal Reserve System 1999. Federal reserve bulletin 85 . Washington, DC: Board of Governors of the Federal Reserve System.

Brown, C. O., \& Dinç, I. S. 2011. Too many to fail? Evidence of regulatory forbearance when the banking sector is weak. Review of Financial Studies, 24(4): 1378-1405.

Bushman, R., \& Williams, C. 2015. Delayed expected loss recognition and the risk profile of banks. Journal of Accounting Research, 53(3): 511-553.

Cerutti, E., Dell'Ariccia, G., \& Martínez Pería, M. 2007. How banks go abroad: Branches or subsidiaries? Journal of Banking and Finance, 31(6): 1669-1692.

Chen, S., Miao, B., \& Shevlin, T. 2015. A new measure of disclosure quality: The level of disaggregation of accounting data in annual reports. Journal of Accounting Research, 53(5): 1017-1054.

Čihák, M., Demirgüç-Kunt, A., Pería, M., \& Mohseni-Cheraghlou, A. 2012. Bank regulation and supervision around the world: A crisis update. In: Policy research working paper 6286, The World Bank.

Cull, R., Senbet, L., \& Sorge, M. 2005. Deposit insurance and financial development. Journal of Money, Credit, and Banking, 37(1): 43-82.

DeFond, M., \& Zhang, J. 2014. A review of archival auditing research. Journal of Accounting and Economics, 58(2-3): 275-326.

Demirgüç-Kunt, A., Kane, E., \& Laeven, L. 2015. Deposit insurance around the world: A comprehensive analysis and database. Journal of Financial Stability, 20(3): 155-183.

D'Hulster, K. 2012. Cross border banking supervision: Incentive conflicts in supervisory information sharing between home and host supervisors. Journal of Banking Regulation, 13: 300-319.

Fang, Y., Hasan, I., Leung, W. S., \& Wang, Q. 2019. Foreign ownership, bank information environments, and the international mobility of corporate governance. Journal of International Business Studies, 50(9): 1566-1593.

Fiechter, J., Ötker, I., Ilyina, A., Hsu, M., Santos, A., \& Surti, J. 2011. Subsidiaries or branches: Does one size fit all? In: IMF staff discussion notes no. 11/04, international monetary fund.

Frame, W. S., Mihov, A., \& Sanz, L. 2020. Foreign investment, regulatory arbitrage, and the risk of US banking organizations. Journal of Financial and Quantitative Analysis, 55(3): 955-988.

Francis, J., \& Wang, D. 2008. The joint effect of investor protection and Big 4 audits on earnings quality around the world. Contemporary Accounting Research, 25(1): 157-191.

Green, R. C. 1984. Investment incentives, debt, and warrants. Journal of Financial Economics, 13(1): 115-136.

Greene, W. 2004. The behavior of the maximum likelihood estimator of limited dependent variable models in the presence of fixed effects. Econometrics Journal, 7(1): 98-119.

Harford, J., Klasa, S., \& Walcott, N. 2009. Do firms have leverage targets? Evidence from acquisitions. Journal of Financial Economics, 93(1): 1-14.

Healy, P. M., \& Palepu, K. G. 2001. Information asymmetry, corporate disclosure, and the capital markets: A review of the empirical disclosure literature. Journal of Accounting and Economics, 31(1-3): 405-440.

Houston, J. F., James, C., \& Marcus, D. 1997. Capital market frictions and the role of internal capital markets in banking. Journal of Financial Economics, 46(2): 135-164.

Houston, J. F., Lin, C., \& Ma, Y. 2012. Regulatory arbitrage and international bank flows. Journal of Finance, 67(5): 1845-1895.

IMF 2014a. Global financial stability report: Moving from liquidity to growth-driven markets. Washington, DC: International Monetary Fund.

IMF 2014b. Cross-border bank resolution: Recent developments. Washington, DC: International Monetary Fund. lyer, R., \& Puri, M. 2012. Understanding bank runs: The importance of depositor-bank relationships and networks. American Economic Review, 102(4): 1414-1445.

John, K., Saunders, A., \& Senbet, L. 2000. A theory of bank regulation and management compensation. Review of Financial Studies, 13(1): 95-125.

Kanagaretnam, K., Lim, C. Y., \& Lobo, G. 2014. Influence of national culture on accounting conservatism and risk-taking in the banking industry. The Accounting Review, 89(3): 1115-1149.

Karolyi, G. A., \& Taboada, A. G. 2015. Regulatory arbitrage and cross-border bank acquisitions. Journal of Finance, 70(6): 2395-2450.

Kostova, T., Beugelsdijk, S., Scott, W. R., Kunst, V. E., Chua, C. H., \& van Essen, M. 2020. The construct of institutional distance through the lens of different institutional perspectives: Review, analysis, and recommendations. Journal of International Business Studies, 51(4): 467-497.

Kostova, T., Nell, P. C., \& Hoenen, A. K. 2016. Understanding agency problems in headquarters-subsidiary relationships in multinational corporations: A contextualized model. Journal of Management, 44(7): 2611-2637.

Laeven, L., \& Levine, R. 2009. Bank governance, regulation, and risk taking. Journal of Financial Economics, 93(2): 259-275.

Laeven, L. 2013. Corporate governance: What's special about banks? Annual Review of Financial Economics, 5(1): 63-92.

Lambert, R., Leuz, C., \& Verrecchia, R. 2007. Accounting information, disclosure, and the cost of capital. Journal of Accounting Research, 45(2): 385-420.

Lehmann, M. 2016. Volcker rule, ring-fencing or separation of bank activities-Comparison of structural reform acts around the world. Journal of Banking Regulation, 17(3): 176-187.

Li, D., Moshirian, F., Pham, P. K., \& Zein, J. 2006. What financial institutions are large shareholders: the role of macro corporate governance environments. Journal of Finance, 61(6): 2975-3007.

Mayer, T., \& Zignago, S. 2011. Notes on CEPII's distances measures: The geodist database. Working paper, Centre $d^{\prime}$ Etudes Prospectives et d'Informations Internationales (CEPII).

Ongena, S., Popov, A., \& Udell, G. F. 2013. When the cat's away the mice will play: Does regulation at home affect bank risk taking abroad? Journal of Financial Economics, 108(3): 727-750.

Roodman, D. 2011. Fitting fully observed recursive mixedprocess models with CMP. The Stata Journal, 11(2): 159-206.

Roth, K., \& O'Donnell, S. W. 1996. Foreign subsidiary compensation strategy: An agency theory perspective. Academy of Management Journal, 39(3): 678-703.

Staiger, D., \& Stock, J. H. 1997. Instrumental variables regression with weak instruments. Econometrica, 65(3): 557-586.

Verrecchia, R. E. 1983. Discretionary disclosure. Journal of Accounting and Economics, 5: 179-194.

World Bank. 2019. Global financial development report 2019/2020: Bank regulation and supervision: The decade after the Global Financial Crisis. Washington, DC: World Bank.

\section{APPENDIX A: VARIABLE DEFINITION}

\section{Variables of Interest}

RESTRICT: A country-level index of regulatory restrictions on bank activities. This index measures 
the regulatory impediments to a bank's engagement in securities (underwriting, brokering, dealing in securities, and all aspects of the mutual fund industry), insurance (insurance underwriting and selling), and real estate (real estate investment, development, and management) activities. The index ranges from 3 to 12, with higher values indicating more activity restrictions on banks (including either banks or subsidiaries, or in another part of a holding company or parent). Source: Barth et al. (2013).

$\triangle$ RESTRICT: The index of home-country activity restrictions minus the index of host-country activity restrictions. Source: Barth et al. (2013).

$\triangle$ RESTRICT_SEC: The index of home-country securities activity restrictions minus the index of hostcountry securities activity restrictions. This index measures the extent to which banks may engage in underwriting, brokering, and dealing in securities, and all aspects of the mutual fund industry. The index ranges from 1 to 4 , with higher values indicating more restrictions on banks (including either banks or subsidiaries, or in another part of a common holding company or parent). Source: Barth et al. (2013).

$\triangle$ RESTRICT_INS: The index of home-country insurance activity restrictions minus the index of hostcountry insurance activity restrictions. This index measures the extent to which banks may engage in insurance underwriting and selling. The index ranges from 1 to 4 , with higher values indicating more restrictions on banks (including either banks or subsidiaries, or in another part of a common holding company or parent). Source: Barth et al. (2013).

$\triangle$ RESTRICT_REAL: The index of home-country real estate activity restrictions minus the index of hostcountry real estate activity restrictions. This index measures the extent to which banks may engage in real estate investment, development, and management. The index ranges from 1 to 4 , with higher values indicating more restrictions on banks (including either banks or subsidiaries, or in another part of a common holding company or parent). Source: Barth et al. (2013).

DISCLOSURE: The sum of DISCLOSURE_LOAN and DISCLOSURE_SEC. The index ranges from 0 to 7 , with higher values indicating more transparent financial reporting. Source: Bankscope.

DISCLOSURE_LOAN: An index formed by adding one when the bank discloses (1) any of the loan types, (2) the amount of loan loss provisions, and (3) the amount of non-performing loans. The index ranges from 0 to 3 , with higher values indicating more transparent financial reporting on loan quality. Source: Bankscope.

DISCLOSURE_SEC: An index formed by adding one when the bank discloses (1) any of the securities types, (2) any of the securities issuing party, (3) the amount of gains (losses) on trading and derivatives, and (4) the amount of available-for-sale valuation adjustments. The index ranges from 0 to 4 , with higher values indicating more transparent financial reporting on securities holdings and profits. Source: Bankscope.

BANK FAILURE: An indicator variable equal to one if a bank ceases to have financial statement information during 2007-2009 and becomes inactive thereafter. Source: Bankscope.

LARGE DEPOSIT WD: An indicator variable equal to one if an annual deposit growth of a bank lies at the bottom $10 \%$ ile of the distribution of the overall deposit growth (with a cutoff of $-23.56 \%$ ) during the crisis period 2007-2009. Source: Bankscope.

\section{Other Country-Level Variables}

$\triangle$ SUPV POWER: The index of home-country supervisory power minus the index of host-country supervisor power. Supervisory power index measures the extent to which the bank supervisors can take specific actions to prevent or correct problems. This index ranges from 0 to 14, with higher values indicating stronger supervisory power. Source: Barth et al. (2013).

$\triangle$ DEPOSIT INS: The index of home-country deposit insurance minus the index of host-country deposit insurance. Deposit insurance index is an indicator variable equal to one if there is an explicit deposit insurance and depositors were fully compensated the last time a bank failed. Source: Barth et al. (2013).

ENTRY BARRIER: A measure of the limitation on foreign bank entry/ownership. This index ranges 
from 0 to 4, with higher values indicating greater stringency. Source: Barth et al. (2013).

GGO: A measure of country-specific growth opportunities implied by the global market. Source: Bekaert et al. (2007).

\section{Other Firm-Level Variables}

SIZE: The log of lagged total assets (in USD millions). Source: Bankscope.

ROA: Return on assets, measured as net income scaled by lagged total assets. Source: Bankscope.

LOAN GROWTH: The percentage change in total loans over the year. Source: Bankscope.

CAPITAL RATIO: Equity divided by lagged total assets. Source: Bankscope.

BIG 5: An indicator variable equal to 1 if the bank is a client of a Big Five auditor. Source: Bankscope.

PUBLIC: An indicator variable equal to 1 if the bank is publicly listed. Source: Bankscope.

SAME LANGUAGE: An indicator variable equal to 1 if the home and host countries share the same official language. Source: Mayer and Zignago (2011).

LOG Z: The log of the distance to default, measured as mean (ROA+CAR)/volatility (ROA) over the fiveyear period from year $t-4$ to year $t$. ROA is the return on assets, CAR is the capital to asset ratio, and volatility (ROA) is the standard deviation of ROA. Source: Bankscope.

QUALIFIED OP: An indicator variable equal to 1 if the bank receives a qualified audit opinion. Source: Bankscope.

DEAL PAYMENT: An indicator variable equal to 1 if the acquisition payment method is cash. Source: Zephyr.

\section{ABOUT THE AUTHORS}

Tai-Yuan Chen is a Professor of Accounting at the School of Business and Management in Hong Kong University of Science and Technology. He received his PhD from the University of Texas at Dallas, and his research focuses on executive compensation, ownership structure, and auditing. He has published in leading accounting and finance journals.

Yi-Chun Chen is an Assistant Professor of Accountancy at the City University of Hong Kong. She received her PhD from the Hong Kong University of Science and Technology. Her research primarily focuses on the disclosure by financial institutions and the corporate social responsibility reporting.

Mingyi Hung is the Fung Term Professor of Accounting at Hong Kong University of Science and Technology. She received her PhD from MIT. Her research focuses on financial disclosures and institutional development in global capital markets. She is a former Editor of The Accounting Review and has published in various leading academic journals.

Open Access This article is licensed under a Creative Commons Attribution 4.0 International License, which permits use, sharing, adaptation, distribution and reproduction in any medium or format, as long as you give appropriate credit to the original author(s) and the source, provide a link to the Creative Commons licence, and indicate if changes were made. The images or other third party material in this article are included in the article's Creative Commons licence, unless indicated otherwise in a credit line to the material. If material is not included in the article's Creative Commons licence and your intended use is not permitted by statutory regulation or exceeds the permitted use, you will need to obtain permission directly from the copyright holder. To view a copy of this licence, visit http://creativecommons.org/licenses/by/4.0/.

Publisher's Note Springer Nature remains neutral with regard to jurisdictional claims in published maps and institutional affiliations.

Accepted by Lemma Senbet, Area Editor, 15 November 2021. This article has been with the authors for four revisions. 